\title{
Expedited Technology Demonstration Project Baseline \\ Revision 3.0
}

\author{
M. G. Adamson \\ P. J. Densley
}

October 1996

This is an informal report intended primarily for internal or limited external distribution. The opinions and conclusions stated are those of the author and may or may not be those of the Laboratory.

Work performed under the auspices of the U.S. Department of Energy by the Lawrence Livermore National Laboratory under Contract W-7405-Eng-48. 


\section{DISCLAIMER}

This document was prepared as an account of work sponsored by an agency of the United States Government. Neither the United States Government nor the University of California nor any of their employees, makes any warranty, express or implied, or assumes any legal liability or responsibility for the accuracy, completeness, or usefulness of any information, apparatus, product, or process disclosed, or represents that its use would not infringe privately owned rights. Reference herein to any specific commercial product, process, or service by trade name, trademark, manufacturer, or otherwise, does not necessarily constitute or imply its endorsement, recommendation, or favoring by the United States Government or the University of California. The views and opinions of authors expressed herein do not necessarily state or reflect those of the United States Government or the University of California, and shall not be used for advertising or product endorsement purposes.

This report has been reproduced directly from the best available copy.

Available to DOE and DOE contractors from the Office of Scientific and Technical Information

P.O. Box 62, Oak Ridge, TN 37831

Prices available from (615) 576-8401, FTS 626-8401

Available to the public from the

National Technical Information Service

U.S. Department of Commerce

5285 Port Royal Rd.,

Springfield, VA 22161 


\section{Expedited Technology Demonstration Project}

(Revised Mixed Waste

Management Facility Project)

Project Baseline

Revision 3.0

and

FY97 Plan

October 1996 



\section{Contents}

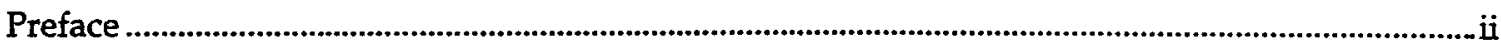

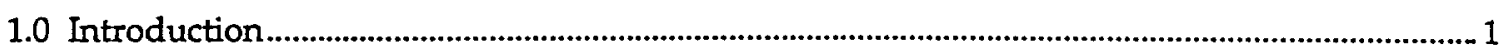

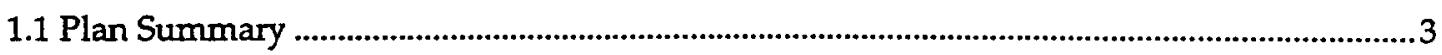

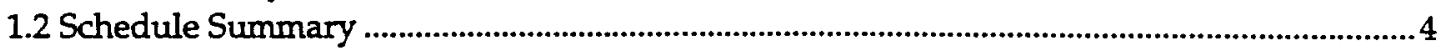

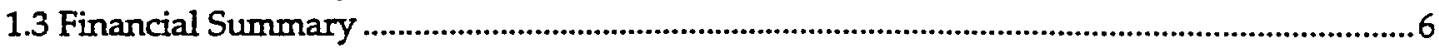

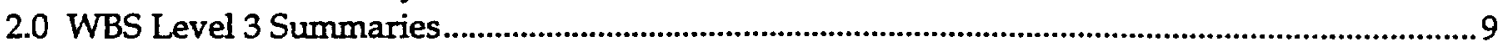

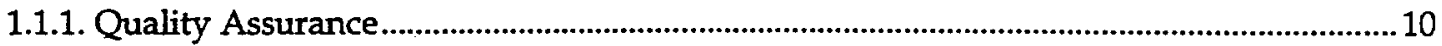

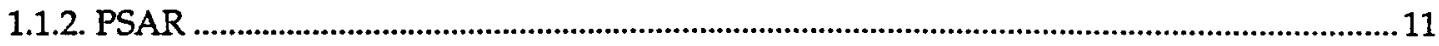

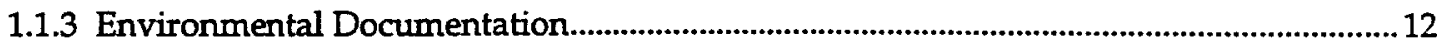

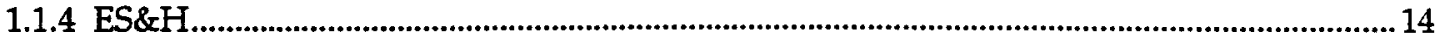

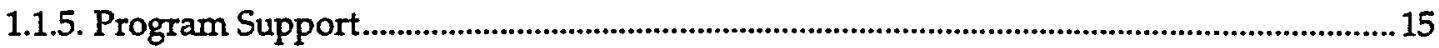

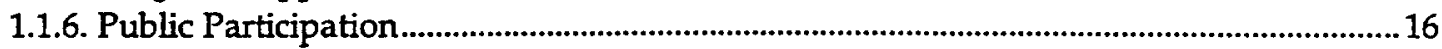

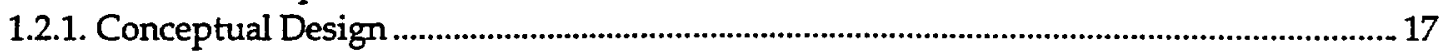

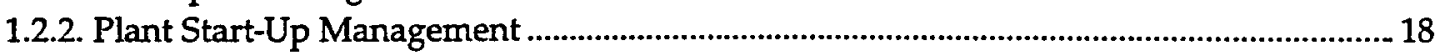

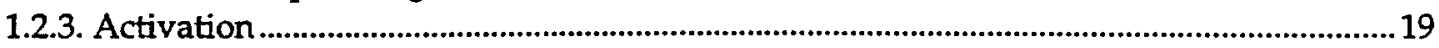

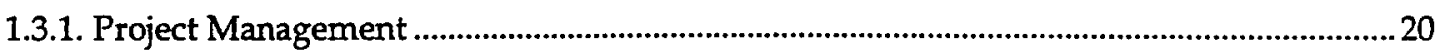

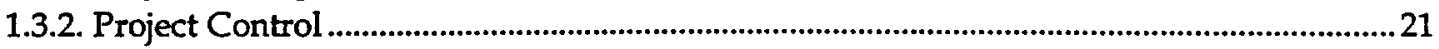

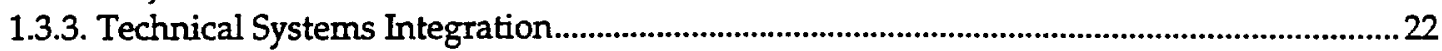

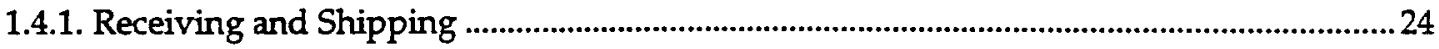

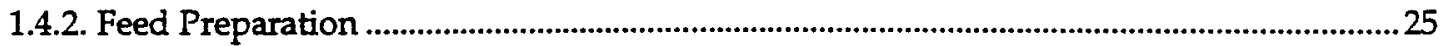

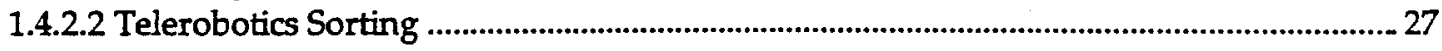

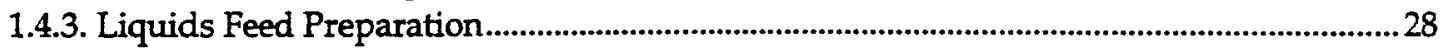

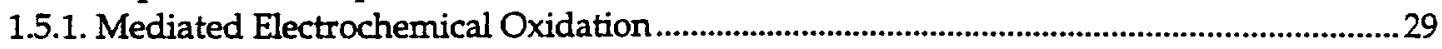

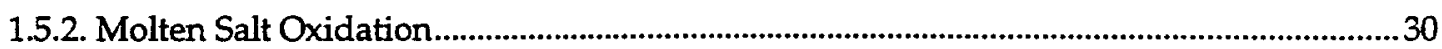

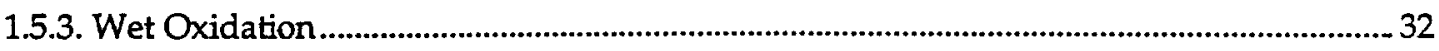

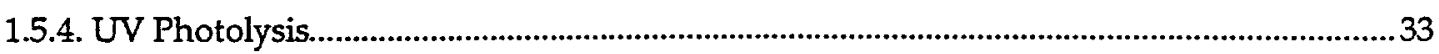

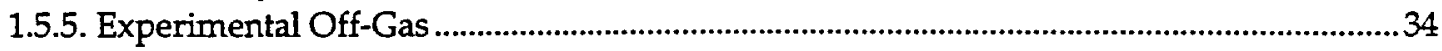

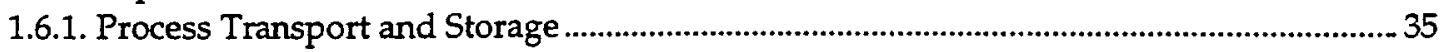

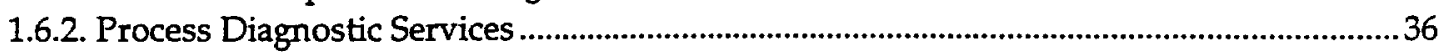

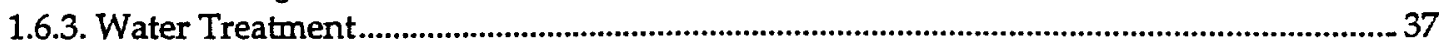

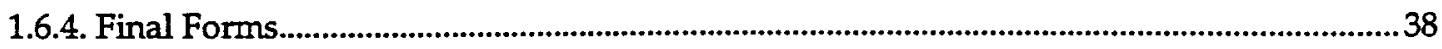

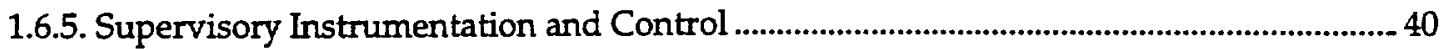

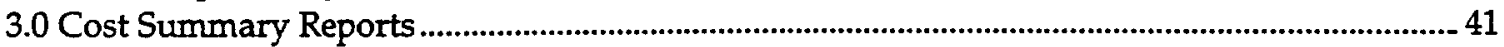

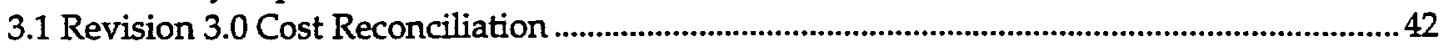

3.2 Project Cost Summary, Unescalated, without MR .......................................................................4 43

3.3 Project Cost Summary, Unescalated, with MR............................................................................44

3.4 Project Cost Summary, Escalated, with MR ...........................................................................45

Appendices

Appendix A: LLNL Proposed Reconfiguration Letter to S. Cowan

Appendix B: Revision 2.2 Guidance

Appendix C: DOE Approval Letter

Appendix D: Project Baseline Revision Log

Appendix E. Revision 3.0 Milestone Log

Appendix F: MSO Process Demonstration Plan 


\author{
Expedited Technology Demonstration Project \\ (revised Mixed Waste Management Facility Project) \\ Project Baseline Revision 3.0
}

\title{
Preface
}

This rebaseline of the Mixed Waste Management Facility Project is designated as "Project Baseline Revision 3.0." Although the last approved baseline was identified as 1.2, DOE guidance for the Project Preliminary Design resulted in a rebaseline document 2.0. Revision 2.0 was completed in January 1996 subsequent to the Preliminary Design Review (November 1995), however, was put on hold pending DOE decision on proceeding with the MWMF Project. When it became clear that the Project would not be approved as revised due to funding constraints, Revision 2.0 was issued to document DOE guidance and the Project Plan as of the Preliminary Design. Revision 2.0 was sent to DOE in April 1996. Revision 2.1 was then initiated which still coordinated activities with DWTF, but was significantly reduced in scope - in line with expected DOE guidance. Revision 2.1 was an internal revision to focus design efforts on more attainable milestones and was not issued as a formal baseline document. Project Baseline Revision 2.2, was also based on informal DOE guidance, and incorporated further reductions in scope and separation from the DWTF complex. Revision 2.2 was sent to DOE in June 1996, but not approved. Project Baseline Revision 3.0 is based upon formal DOE guidance, and incorporates further reductions in scope due to funding limitations.

This revised baseline document details the system deployment phase of the project covering FY97 through FY98. As originally discussed with DOE, the plan was to complete the expedited demonstration in FY97 based on a funding profile of $\$ 3.5 \mathrm{M}$ for the remainder of FY96 and $\$ 3.0 \mathrm{M}$ in FY97. However due to further budget constraints and carryover issues, only $\$ 2.0 \mathrm{M}$ was approved for FY97 (see Appendices A - C). As such, essentially all MSO operational demonstration activities will be completed in FY98 and the integration with final forms delayed until FY98 unless the complete FY96 carryover moneys are used. This option is addressed in the Final Forms area as "Management Reserve". The feed preparation activities have been deleted in this baseline and only provides a minimal decontamination function in FY98. 


\subsection{Introduction}

The Expedited Technology Demonstration Project Plan, MWMF Revised Baseline 3.0, replaces and significantly modifies the MWMF current baseline. The revised plan will focus efforts specifically on the demonstration of an integrated Molten Salt Oxidation (MSO) system. In addition to the MSO primary unit, offgas, and salt recycle subsystems, the demonstrations will include the generation of robust final forms from process mineral residues. A simplified process flow chart for the expedited demonstration is shown in Fig. 1.0-1. To minimize costs and to accelerate the schedule for deployment, the integrated system will be staged in an existing facility at LLNL equipped to handle hazardous and radioactive materials. The MSO systems will be activated in FY97, followed by the activation of final forms in FY98. 


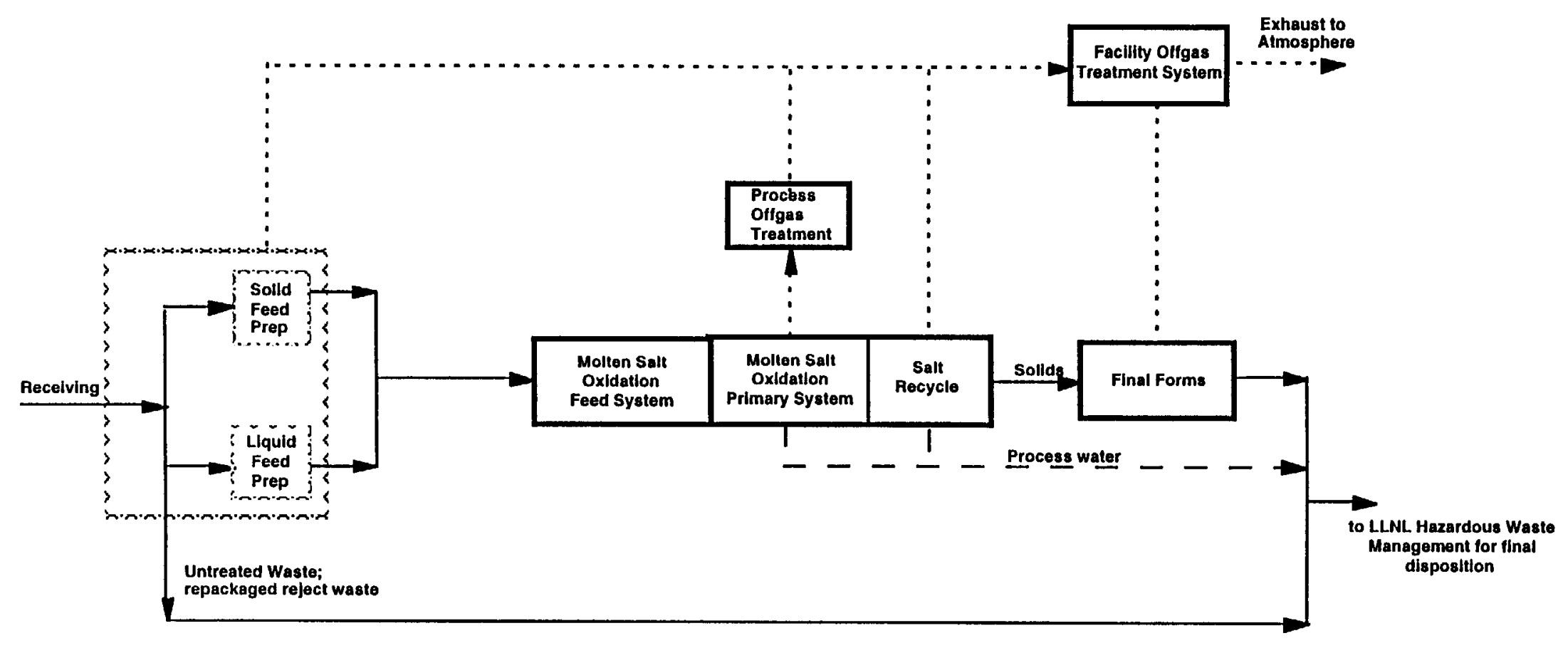

Figure 1.0-1 Expedited Technology Demonstration Flow Diagram 


\subsection{Plan Summary}

The mission and goals of the expedited technology demonstration will be to:

- Deploy a fully integrated MSO system that can be transitioned to treatment as required.

- Resolve conclusively the value of MSO as an integrated system for the treatment of mixed, radioactive and hazardous waste by demonstrating

- operability of all major system components

- engineered features of molten salt system

- organic destruction efficiency for both solid and liquid feeds

- control and retention of toxic constituents

- separation of mineral residues from spent salt

- ability to clean salt to meet LDR

- preparation of solid and liquid surrogate and mixed waste (if additional funding is provided) streams for treatment by MSO

- preparation and effectiveness of ceramic final forms

- Coordinate deployment with industrial partners.

- Coordinate engineering development, design, and system operations data with DOE's Defense Programs (HE destruction) and DoD (energetic materials and hazardous waste treatment) molten salt activities.

- Support California EPA interest in evaluating technologies which are alternatives to incineration for commercial hazardous and mixed waste processing (e.g., medical, R\&D, etc.)

Although significantly down scoped from the original project, the basic goal - to evaluate the effectiveness of an alternative to incineration - is maintained. In addition, this solution also preserves the more global requirement to involve stakeholders, regulators, and industrial participants who are critical to the success of future deployment.

To provide for the broadest possible application of MSO technology, the system will be down-sized and reconfigured. The complete system will be configured so that it may be skid mounted for relocation. This has the following advantages:

- Easily moved to and set-up at a permitted site for treatment of waste, or for the demonstration of treatment capability at other sites;

- Increased opportunities to demonstrate additional commercial applications;

- Modularity will significantly reduce facility costs. 


\subsection{Schedule Summary}

The Project Schedule (IPS) associated with this Project Baseline revision is presented in Figure 1.2-1. Key milestones include:

- Final design complete

$10 / 96$

- Beneficial occupancy of Bldg. 292, begin staging of systems

$4 / 97$

- Approval to Operate, begin surrogate testing in MSO

$8 / 97$

- Approval to initiate treatability studies in MSO

$2 / 98$

- Initiate operations of integrated MSO system

$4 / 98$

- Project complete - system fully operational and initial demonstration completed.

$9 / 98$

Appendix $\mathrm{E}$ is an updated milestone $\log$ for this project. Because of the significant change in Project scope and schedule, all existing previous milestones are being superseded by the revised plan. To avoid confusion, a new numbering sequence will be used; milestones for the Expedited Demonstration will start with an " $E$ " followed by a three-digit number indicating the WBS element, and finally, a milestone number.

To meet the very aggressive schedule for deploying the MSO system and to reduce the amount of potential unencumbered funds carryover to FY97, major procurements were initiated during final design. As key elements were designed and approved for purchase/fabrication, including many of the standard pieces of equipment, e.g., pumps, tanks, etc., purchase requisitions were submitted placing a lien on FY96 funding. Most equipment, however will not be costed until delivery in FY97. To protect against purchasing equipment which has only a very limited applicability, the project coordinated its requirements with HWM where appropriate (e.g., feed handling and preparation equipment).

It is pointed out that if the $\$ 337 \mathrm{~K}$ of unobligated carryover from FY96 is not available for use as shown in the Final Forms area (Management Reserve), there is inadequate funding to do any work other than close-out documentation in FY97. Restarting Final Forms at a later date will certainly incur additional costs in FY98 as well as potential problems with staffing and schedule delays.

The installation, test, and acceptance phases of the Project have been significantly reduced and integrated into the technical elements where possible. Where pre-staging is appropriate prior to availability of Bldg. 292, equipment will be set-up in Bldg. 241 for check-out.

The schedule also calls for continuing demonstrations into FY98. Under the current DOE plans, however, funding into FY98 is not fully resolved (see Appendix (), and only system demonstration guidance is included in Appendix F. A formal plan for these actives will be developed at a later date. 
Expedited Technology Demonstration Schedule
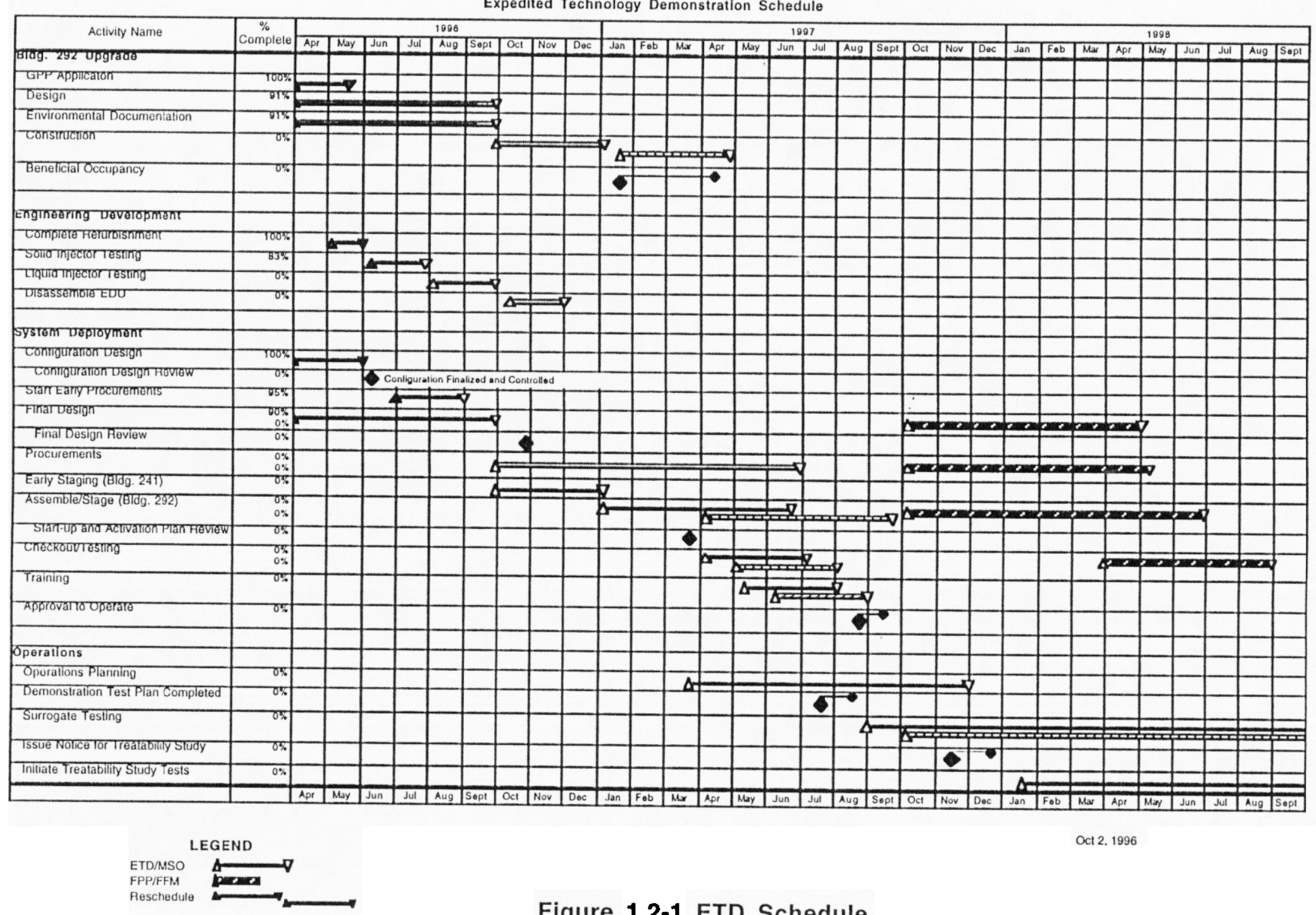

Figure 1.2-1 ETD Schedule 


\subsection{Financial Summary}

Cost estimates are based on a revised estimate using data generated in preparing Project Baseline 2.0. As with the Project Baseline 2.0, Excel spreadsheets which automatically apply the proper LLNL overhead taxes, depending on cost type, were used. Schedule information for each activity were also entered into the spreadsheets. Unlike the previous effort, however, the files will not be translated and up-loaded into Primavera for cost roll-up and schedule generation. Rather, the Excel spreadsheets will be used directly for both funding and schedule information. The "9 Sheet Excel Workbook" will be utilized to summarize costs, add Management Reserve, and apply escalation to out-year costs. Cost reconciliation and other detail financial information are contained in Section 3.0. The summary tables in Section 3 are generated directly from this workbook.

The table below shows the funding for the system deployment and demonstrations as approved by DOE, and the funding agreed upon with LLNL for facility upgrade. Funding is included to complete the MSO system deployment and initial phase of demonstrations in the latter months of FY97. Completion of the integrated system with the addition of final forms, and treatability studies will continue into FY98.

\begin{tabular}{|l|c|c|c|}
\hline Funding Source & $\begin{array}{c}\text { May 96 } \\
\text { to end of } \\
\text { FY96 } \\
\text { (\$M) }\end{array}$ & FY97 & FY98 \\
\hline (\$M) & $(\$ M)$ \\
\hline DOE EM-30 & 3.5 & 2.0 & 2.0 \\
Commercial support (est.) & 0.3 & 1.0 & 1.0 \\
Upgrade of Bldg. 292 & & 0.7 & \\
\hline
\end{tabular}

The revised TPC for the MWMF Project has been reduced to $\$ 25.8 \mathrm{M}$. The cost to go for FY97 and FY98 has been set per DOE guidance with a basic philosophy of "build to cost." In general, all costs associated with facility infrastructure or the general testbed mission have been eliminated. Instrumentation and controls and other support systems have been down scoped to specifically meet the demonstration requirements of MSO. Additionally Plant Start-up and Activation activities have be reduced to the start up of the demonstration systems. Much of the external interactions have also been significantly reduced or eliminated.

\section{Summary of Changes Reported in Section 2}

Cost estimate data was developed for the Preliminary Design, Title I, Project Baseline 2.0. This data has been significantly modified to reflect the major changes in scope and schedule directed by DOE. Based on discussions with DOE, 
the system design will be sized so as to meet budget constraints. As such, the cost estimate will be well defined, however, the "contingency" will be in the scope of the deliverable system.

Section 2 contains details of scope and cost for the revised plan at each WBS Level 3. Following is a summary of the major cost changes associated with this revision:

- Project Management / Project Control / Technical Systems Integration: Management functions covered under this element include both fixed cost and level-of-effort activities. A major component of the fixed cost is the OFC charges for offices. This will be reduced by reducing the size of the project team and consolidating into one Trailer, T1877. The level of effort activities will also be reduced as much as possible by reducing staff. As such, project management and reporting will be reduced to a skeletal effort.

- Feed Preparation: Within the current budget guidelines, the feed preparation equipment will not be installed, nor will the required enclosures for handling hazardous and radioactive materials be procured. A minimal decon capability will be provided in FY98 to allow containers to be removed from B292. Surrogate feeds can be procured and HWM can supply certain targeted mixed waste feeds.

- Molten Salt Oxidation: This is a key element of the Expedited Technology Demonstration Project. A revised system design will be completed based on encompassing all elements of a treatment train including: feed distribution, primary reactor, offgas, and salt recycle systems, however not all will have plant-like operations.

- Final Forms: This is a key element of the Expedited Technology Demonstration Project. The revised design effort will be directed to meeting the schedule/cost profile with emphasis on ceramic final forms, however, back-up capability for salt polymer encapsulation will be maintained. To meet these criteria, procurement of final forms equipment has been deferred from FY96 to FY97. The major portion of the final forms work is now scheduled to begin the last quarter of FY97 and into FY98, funding permitting.

- Process Diagnostic Services: Effort will be on an as requested basis. Under the new scope, no new equipment will be procured for an analytical laboratory and a LIMS system will not be deployed. 
- Receiving and Shipping, Water Treatment, Mediated Electrochemical Oxidation, Process Transport and Storage, Supervisory Instrumentation and Control: These elements have been closed under the reduced scope. 


\subsection{WBS Level 3 Summaries}

In this section, the specific plan for FY97 is discussed relative to each WBS element. Each specific plan is divided into 5 topics: Task Description, FY97 Plan, Budget, Procurement, and Milestones and Markers. The "Task Description" is duplicated from the WBS dictionaries as previously approved. The "Task Descriptions" required modification and can be compared with earlier versions, if required. The budget shown, by month, is the total expected commitment to the account. It includes all manpower and expenses as well as liens on that element. To this procurements are added when the order is expected to be costed. Consistent with this budget estimate, procurements identified in the following tables are based on the date the order is expected to be placed. The last section is a new milestone and marker list base on the revised project plan. All previous milestones and markers associated with the previous plans are being suspended in light of the major change in project scope. To avoid confusion, new LLNL milestones and markers are identified with a suffix " $E$ " indicating they relate to the expedited demonstration. 
WBS Element 1.1.1. Quality Assurance

Task Description

Quality Assurance provides quality assurance (QA) support to the ETD Project. This effort includes development and implementation of the Project's QA program and oversight for conformance to the approved plan and other quality and ES\&H requirements. This WBS element covers only a proportional fraction of the OPEX QA effort, with the CENRTC portion contained under WBS 1.3.2, Project Control.

\section{FY97 Plan}

The majority of QA activities prior to Start-Up and Activation are covered under CENRTC cost elements. Minimal support is identified in operations beginning in the 2nd Quarter of FY98.

\section{Budget}

FY97 Spending profile (\$K, OPEX)

\begin{tabular}{|c|c|c|c|c|c|c|c|c|c|c|c|c|c|}
\hline & Ot & Nov & Dec & Jan & Feb & Mar & Apr & Nay & Jun & Jul & Aug & Sep & Total \\
\hline Revised Plan & 0 & 0 & 0 & 0 & 0 & 0 & 0 & 0 & 0 & 0 & 0 & 0 & 0 \\
\hline
\end{tabular}

Total Element Costs to Date (thru 9/96): $\$ 127 \mathrm{~K}$.

Estimated Liens into FY98: None

Major FY97 Procurements

None

FY98

Total Budget (\$K, OPEX): $\quad$ \$27K

Total Procurements: None

Milestones and Markers

ID No. Milestone/Marker

None 


\section{WBS Element 1.1.2. PSAR}

\section{Task Description}

The Preliminary Safety Analysis Report (PSAR) provides the integration of safety input, design reviews, and safety analysis for the ETD Project. Safety analysis includes analysis, generation of documentation, and documentation review and approval. The element includes the generation of the PSAR, which must be completed prior to major procurements and follow-on analysis required for the generation of the Final Safety Analysis Report (FSAR). The FSAR is required after construction and prior to operation.

\section{FY97 Plan}

PSAR was revised for Building 292 in FY96. No activities are planned for FY97/FY98.

\section{Budget}

FY97 Spending profile (\$K, CENRTC)

\begin{tabular}{|c|c|c|c|c|c|c|c|c|c|c|c|c|c|}
\hline & Ot & Nov & Dec & an & Feb & Mar & Apr & May & Jun & Jul & Aug & Sep & Total \\
\hline Revised Plan & 0 & 0 & 0 & 0 & 0 & 0 & 0 & 0 & 0 & 0 & 0 & 0 & 0 \\
\hline
\end{tabular}

Total Element Costs to Date (thru 9/96): $\$ 367 \mathrm{~K}$.

Estimated Liens into FY98: None

Major FY97 Procurements

None

FY98

Total Budget (\$K, CENRTC): \$OK

Total Procurements: None

Milestones and Markers

ID No. Milestone/Marker

Scheduled

None 


\section{WBS Element 1.1.3 Environmental Documentation}

\section{Task Description}

The National Environmental Policy Act (NEPA) portion of this WBS element provides for the preparation of the Environmental Assessment (EA) and all required follow-up documentation required by DOE to make a determination about impacts. The effort includes preliminary evaluations, preparation of technical information, EA preparation, and comment resolution.

The California Environmental Quality Act (CEQA) and permitting portion of this WBS element provide for the preparation of permit applications and associated environmental analysis to support the regulatory agency permitting and CEQA review process. The effort includes preliminary evaluations, preparation of technical information to support the agency CEQA document and permit evaluation, and comment resolution. This element prepares and coordinates approval of State and local permits and supports public participation activities associated with the permit approvals.

\section{FY97 Plan}

Environmental specialists will continue to provide assistance to Project staff to interface with regulatory agencies, prepare necessary documentation such as air permit applications, and advise on hazardous waste management regulations. Documentation will pertain to operations in Building 292 with surrogate feeds and actual waste within treatability study limits.

\section{Budget}

FY97 Spending profile for remainder of FY (\$K, CENRTC)

\begin{tabular}{|c|c|c|c|c|c|c|c|c|c|c|c|c|c|}
\hline & Ot & Nov & Dec & Jan & Feb & Mar & Apr & May & Jun & Jul & Aug & Sep & Total \\
\hline Revised Plan & 0 & 0 & 0 & 0 & 2.0 & 0 & 0 & 1.5 & 1.5 & 1.5 & 1.5 & 1.5 & 9.6 \\
\hline
\end{tabular}

Total Element Costs to Date (thru 9/96): $\$ 386 \mathrm{~K}$.

Estimated Liens into FY98: None

Major FY97 Procurements

None

FY98

Total Budget (\$K, CENRTC): $\quad$ \$OK

Total Procurements: None 


\section{Milestones and Markers}

ID No. Milestone/Marker

Scheduled

C113-1 Authorization to operate issued by BAAQMD

Date

E113-1 Submit air permit to BAAQMD

Oct 97

Aug 97 
WBS Element 1.1.4. ES\&H

\section{Task Description}

ES\&H provides for on-going Environment, Safety, and Health (ES\&H) representation to the ETD Project by ES\&H specialists to ensure that all activities are conducted in a safe and environmentally sound manner and to ensure that ES\&H standards have been properly applied.

\section{FY97 Plan}

ES\&H specialists, as requested, will provide review and guidance to ETD staff on proposed designs to ensure that activities are performed in a safe and compliant manner.

\section{Budget}

FY97 Spending profile (\$K, OPEX)

\begin{tabular}{|c|c|c|c|c|c|c|c|c|c|c|c|c|c|}
\hline & Ot & Nov & Dec & Jan & Feb & Mar & Apr & May & Jun & Jul & Aug & Sep & Total \\
\hline Revised Plan & 1.5 & 1.5 & 1.5 & 1.5 & 1.5 & 1.5 & 1.5 & 1.5 & 1.5 & 1.5 & 1.5 & 1.5 & 17.5 \\
\hline
\end{tabular}

Total Element Costs to Date (thru 9/96): \$391K.

Estimated Liens into FY98: None

Major FY97 Procurements

None

FY98

Total Budget (\$K, OPEX): $\quad$ \$18K

Total Procurements: None

\section{Milestones and Markers}

\begin{tabular}{lll} 
ID No. & Milestone/Marker & $\begin{array}{c}\text { Scheduled } \\
\text { Date }\end{array}$ \\
\hline \hline None & Level of effort activity
\end{tabular}




\section{WBS Element 1.1.5. Program Support}

\section{Task Description}

Program Support provides top-level planning, control, and support of ETD Project OPEX-funded activities. Specific activities include management of project assurances and interface with development activities. This element encompasses support for the Project Office including organization, schedule and budgeting activities, Project plans and reporting, personnel hiring and housing, project operations control, facility technical support, and OPEX-funded technical support.

\section{FY97 Plan}

Management functions covered under this element will be maintained at a minimum. These include, but are not limited to, the following: developing project plans, budgets and schedules; placing personnel; ensuring housing/office requirements for ETD personnel; developing industrial participation; and providing for technical support to the Project office.

\section{Budget}

FY97 Spending profile for remainder of FY (\$K, OPEX)

\begin{tabular}{|l|c|c|c|c|c|c|c|c|c|c|c|c|c|}
\hline & Od & Nov & Dec & Jan & Feb & Mar & Apr & May & Jun & Jul & Aug & Sep & Total \\
\hline Revised Plan & 3.5 & 0 & 0 & 3.5 & 5.5 & 0 & 3.5 & 0 & 5.5 & 0 & 0 & 0 & 21.4 \\
\hline
\end{tabular}

Total Element Costs to Date (thru 9/96): \$2,294K.

Estimated Liens into FY98: None

\section{Major FY97 Procurements}

None

\section{FY98}

Total Budget (\$K, OPEX): \$33K

Total Procurements: None

\section{Milestones and Markers}

\begin{tabular}{|c|c|c|}
\hline IDN & Milestone/Marker & $\begin{array}{l}\text { Scheduled } \\
\text { Date }\end{array}$ \\
\hline V)ne & Level of effort & \\
\hline
\end{tabular}




\section{WBS Element 1.1.6. Public Participation}

\section{Task Description}

Public Participation provides for public input to the planning and execution phases of the ETD Project. Included are a National Review Panel (NRP), a community newsletter (the ETD Letter), and preparation and coordination of press releases and community tours.

\section{FY97 Plan}

Public Participation will continue to support public interactions including the National Review Panel(NRP), public meetings, and newsletters, however, at a significantly reduced funding level. This element will address interactions with the DTSC for establishing a California Certification Program.

\section{Budget}

FY97 Spending profile FY (\$K, OPEX)

\begin{tabular}{|c|c|c|c|c|c|c|c|c|c|c|c|c|c|}
\hline & Od & Nov & Dec & Jan & Feb & Mar & Apr & May & Jun & Jul & Aug & Sep & Total \\
\hline Revised Plan & 4.7 & 0 & 0 & 0 & 0 & 0 & 0 & 0 & 0 & 0 & 1.8 & 0 & 6.5 \\
\hline
\end{tabular}

Total Element Costs to Date (thru 9/96): $\$ 135$.

Estimated Liens into FY98: None

\section{Major FY97 Procurements}

None

FY98

Total Budget (\$K, OPEX): $\quad$ \$3K

Total Procurements: None

\section{Milestones and Markers}

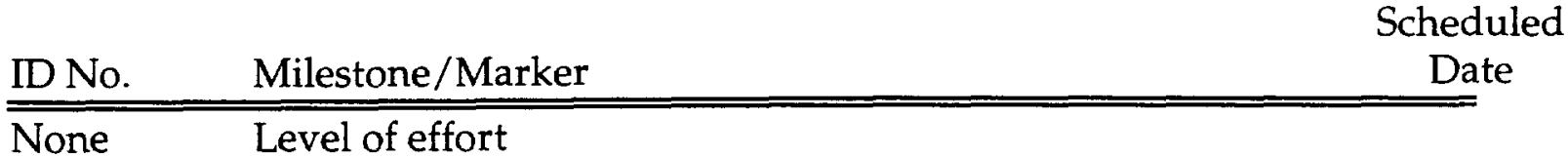




\section{WBS Element 1.2.1. Conceptual Design}

\section{Task Description}

Conceptual Design provides the Project's technical, cost, and schedule baselines that form the basis for KD-1.

\section{FY97 Plan}

The Conceptual Design element is complete. No FY97/FY98 activities.

\section{Budget}

FY97 Spending profile FY (\$K, OPEX)

\begin{tabular}{|c|c|c|c|c|c|c|c|c|c|c|c|c|c|}
\hline & Ot & Nov & Dec & Jan & Feb & Mar & Apr & May & Jun & Jul & Aug & Sep & Total \\
\hline Revised Plan & 0 & 0 & 0 & 0 & 0 & 0 & 0 & 0 & 0 & 0 & 0 & 0 & 0 \\
\hline
\end{tabular}

Total Element Costs to Date (thru 9/96): $\$ 2,235 \mathrm{~K}$.

Estimated Liens into FY98: None

Major FY97 Procurements

None

FY98

Total Budget (\$K, OPEX): $\quad$ \$OK

Total Procurements: None

Milestones and Markers

ID No. Milestone/Marker

None No activity




\section{WBS Element 1.2.2. Plant Start-Up Management}

\section{Task Description}

Plant Start-Up Management provides (1) operations and maintenance review of system designs; (2) the development of top-level plans for staffing, training, testing, and readiness review; (3) task analysis and preparation, review, and revision of site operating plan, maintenance, instrument calibration, and emergency response procedures; (4) recruiting, hiring, clearing, and providing general employee training for the plant staff; and (5) the development of training materials, training the trainers, and special technical and on-the-job training for the plant staff.

\section{FY97 Plan}

The scope/budget of this element has been reduced as a result of the reduced scope of the project. Plant Start-Up activities will begin during the construction and staging phase of the Project when participation in, and review of, the ETD systems from an operational viewpoint commence. Conceptual development of operational methodology, organization, operational and acceptance testing, maintenance, etc., are required to support this effort. Consideration of operational activities to comply with regulatory requirements in support of permitting activities will also occur.

\section{Budget}

FY97 Spending profile (\$K, OPEX)

\begin{tabular}{|c|c|c|c|c|c|c|c|c|c|c|c|c|c|}
\hline & Od & Nov & Dec & Jan & Feb & Mar & Apr & May & Jun & Jul & Aug & Sep & Total \\
\hline Revised Plan & 0 & 0 & 0 & 0 & 0 & 0 & 0 & 0 & 0 & 0 & 0 & 0 & 0 \\
\hline
\end{tabular}

Total Element Costs to Date (thru 9/96): \$1K.

Estimated Liens into FY98: None

\section{Major FY97 Procurements}

None

FY98

Total Budget (\$K, OPEX): $\quad$ \$277K

Total Procurements: None

\section{Milestones and Markers}

ID No. Milestone/Marker

Scheduled

\begin{tabular}{llr}
\hline \hline E122-1 & Issue ETD Start-Up and Activation Plan & Mar 98 \\
E122-2 & Facility Safety Procedure Approved & Feb 98
\end{tabular}




\section{WBS Element 1.2.3. Activation}

\section{Task Description}

Activation provides (1) the preparation, review, revision, and release of all Operational Test Procedures (OTPs); (2) plant systems activation, integration, and performance of OTPs including Operational Readiness Reviews (ORRs); (3) technical support for the preparation of Operational Safety Requirements (OSRs) and Facility Safety Requirements (FSRs), as well as the identification and resolution of problems during plant operational testing, start-up, and activation, including finalization of design documentation for equipment and process modifications; (4) maintenance support to perform equipment or process modifications during start-up, testing, and activation; (5) all operational spares and the initial stores inventory; and (6) all manpower and materials required to deliver support services (e.g., utilities, power, etc.) during construction, testing, and activation of the ETD Expedited Technology Demonstration.

\section{FY97 Plan}

The scope/budget of this element has been reduced as a result of the reduced scope of the project. Activities will be focused on preparation of documentation for obtaining approvals for facility operation, equipment operation, and operations training.

\section{Budget}

FY97 Spending profile (\$K, OPEX)

\begin{tabular}{|c|c|c|c|c|c|c|c|c|c|c|c|c|c|}
\hline & Od & Nov & Dec & Jan & Feb & Mar & Apr & May & Jun & Jul & Aug & Sep & Total \\
\hline Revised Plan & 0 & 0 & 0 & 0 & 0 & 17.7 & 17.7 & 17.7 & 17.7 & 17.7 & 17.7 & 17.7 & 123.8 \\
\hline
\end{tabular}

Total Element Costs to Date (thru 9/96): $\$ 0 \mathrm{~K}$.

Estimated Liens into FY98: None

Major FY97 Procurements

None

FY98

Total Budget (\$K, OPEX):

$\$ 966 \mathrm{~K}$

Total Procurements:

\$219K Building OFC

\section{Milestones and Markers}

ID No.

Milestone/Marker

Scheduled

E123-1 Operational Safety Procedure Approved

E123-2 Operational Test Procedure Approved Date 


\section{WBS Element 1.3.1. Project Management}

\section{Task Description}

Project Management provides top-level project planning, direction, and control of the ETD Project CENRTC-funded systems. Specific activities include project management and support of Project Office, project assurance (including quality assurance, safeguards, environmental, and safety oversight), management overview of information management and technical activities, and interface with DOE.

\section{FY97 Plan}

This effort will encompass project management of the CENRTC phase of the ETD Project. This is essentially a level-of-effort funded activity covering Project management personnel and clerical, administrative, and technical support.

Support for key Project reviews is also included. The FY97 Plan calls for project management oversight of all capital-funded technical and administrative activities, placing personnel, response to DOE requests for information, project scope and budget reassessment, and other management controls to assure effective completion of the milestones and markers of the Project. These efforts will be maintained at a level appropriate for the downsized Project.

\section{Budget}

FY97 Spending profile (\$K, CENRTC)

\begin{tabular}{|c|c|c|c|c|c|c|c|c|c|c|c|c|c|}
\hline & Odt & Nov & Dec & an & Feb & Mar & Apr & May & Jun & Jul & Aug & Sep & Total \\
\hline Revised Plan & 40.4 & 37.4 & 35.0 & 33.9 & 36.9 & 36.9 & 35.0 & 30.4 & 33.4 & 30.4 & 31.6 & 30.4 & 412.0 \\
\hline
\end{tabular}

Total Element Costs to Date (thru 9/96): $\$ 1333 \mathrm{~K}$.

Estimated Liens into FY98: None

Major FY97 Procurements

\$269.5K Office OFC

\section{FY98}

Total Budget (\$K, CENRTC): $\quad \$ 189 \mathrm{~K}$

Total Procurements: \$126 K Office OFC

\section{Milestones and Markers}

\begin{tabular}{lll} 
ID No. & Milestone/Marker & $\begin{array}{c}\text { Scheduled } \\
\text { Date }\end{array}$ \\
\hline \hline None & Level of effort
\end{tabular}




\section{WBS Element 1.3.2. Project Control}

\section{Task Description}

Project Control provides for the Project integration, configuration management, cost and schedule control, QA (see WBS 1.1.1), and administration of the CENRTC-funded systems. It develops and maintains the management systems used to monitor progress against the established baselines and to ensure configuration control (drawings, documents, etc.).

\section{FY97 Plan}

Essential cost, schedule, and technical baseline control using manual and automated interfaces will be provided at a level appropriate for the downsized Project. Activities will include preparation of the Project Baseline Revisions, the FY98 Plan, monthly reports, and other documentation required by DOE. QA procedures that are necessary for the design phase of the Project will be prepared and implemented.

\section{Budget}

FY97 Spending profile (\$K, CENRTC)

\begin{tabular}{|c|c|c|c|c|c|c|c|c|c|c|c|c|c|}
\hline & Ott & Nov & Dec & Jan & Feb & Mar & Apr & May & Jun & Jul & Aug & Sep & Total \\
\hline Revised Plan & 7.4 & 12.4 & 10.4 & 7.4 & 12.4 & 12.4 & 7.4 & 7.4 & 12.4 & 7.4 & 7.4 & 10.4 & 114.9 \\
\hline
\end{tabular}

Total Element Costs to Date (thru 9/96): $\$ 757 \mathrm{~K}$.

Estimated Liens into FY98: None

\section{Major FY97 Procurements}

None

FY98

Total Budget (\$K, CENRTC): $\quad$ \$14 K

Total Procurements: None

\section{Milestones and Markers}

ID No. Milestone/Marker

None Level of effort




\section{WBS Element 1.3.3. Technical Systems Integration}

\section{Task Description}

Technical Systems Integration provides the oversight intended to verify or document system integration performance, system analysis, special process diagnostics, and planning and analysis of the process aspects of integrated tests. It covers technical issues that affect all primary and support processes. It also includes the responsibility for assuring that the systems interfaces are addressed in the final design, including interfaces with LLNL Hazardous Waste Management and facility engineering. The element coordinates the Building 292 upgrade, the facility ETD floor plan, and the Integrated Operating Plan.

\section{FY97 Plan}

Technical Systems Integration will continue to coordinate technical issues that affect all primary and support processes as well as facility interfaces, and the review of the Facility design to ensure the project needs are addressed in the most effective manner. Specifically in FY 97 this effort will be directed to provide facility utilities and equipment arrangements defined in support of the Building 292 upgrade. Work will also be directed to ensure equipment design of the primary and support processes proceed effectively within cost and schedule guidelines. The effort in FY 97 will be focused on the Building 292 upgrade, I\&C software licenses, and the assembly of the process equipment.

\section{Budget}

FY97 Spending profile (\$K, CENRTC)

\begin{tabular}{|c|c|c|c|c|c|c|c|c|c|c|c|c|c|}
\hline & Ot & Nov & Dec & Jan & Feb & Mar & Apr & May & Jun & Jul & Aug & Sep & Total \\
\hline Revised Plan & 31.3 & 26.3 & 19.1 & 24.1 & 19.1 & 7.1 & 12.2 & 7.1 & 7.2 & 7.1 & 12.1 & 7.2 & 180.8 \\
\hline
\end{tabular}

Total Element Costs to Date (thru 9/96): $\$ 589 \mathrm{~K}$.

Estimated Liens into FY98: None

Major FY97 Procurements

None

FY98

Total Budget (\$K, CENRTC): $\quad$ \$OK

Total Procurements: \$OK 


\section{Milestones and Markers}

ID No. Milestone/Marker

Scheduled

E133-4 Final Design Review of equipment

E133-5 Begin B292 construction

E133-6

Complete B292 construction

E133-7 Begin assembly/staging in B292

Date

E133-8

System Operations Review complete

E133-9 Checkout/Testing complete 


\section{WBS Element 1.4.1. Receiving and Shipping}

\section{Task Description}

The principal objective of the Receiving and Shipping (RAS) system is to provide for the receiving, logging, identification and characterization of all incoming waste containers, and to determine the acceptability for processing the waste. RAS provides the management, system analysis and support, design (Title I, II, III) engineering, procurement, installation of RAS equipment, Title III inspection, and acceptance test procedures (ATP). RAS includes both receiving and shipping equipment and systems integration.

\section{FY97 Plan}

This element is closed for the reduced scope project. Receiving and shipping will be an operational function with space allocated in the high bay area of B292 for temporary storage of materials.

\section{Budget}

FY97 Spending profile (\$K, CENRTC)

\begin{tabular}{|c|c|c|c|c|c|c|c|c|c|c|c|c|c|}
\hline & Ot & Nov & Dec & an & Feb & Mar & Apr & May & Jun & Jul & Aug & Sep & Total \\
\hline Revised Plan & 0 & 0 & 0 & 0 & 0 & 0 & 0 & 0 & 0 & 0 & 0 & 0 & 0 \\
\hline
\end{tabular}

Total Element Costs to Date (thru 9/96): $\$ 128 \mathrm{~K}$.

Estimated Liens into FY98: None

Major FY97 Procurements

None

FY97

Total Budget (\$K, CENRTC): $\quad$ \$0K

Total Procurements: None

FY98

Total Budget (\$K, CENRTC): $\quad \$ 0 \mathrm{~K}$

Total Procurements: None

Milestones and Markers

ID No. Milestone/Marker

None No activity




\section{WBS Element 1.4.2. Feed Preparation}

WBS Element 1.4.2 has been divided into Feed Preparation and Demonstration Feed Preparation (Telerobotic Sorting, TRS) activities. Although at the fourth level WBS TRS activities are reported separately under 1.4.2.2.

\section{Task Description}

The principal objective of the Feed Preparation (FP) system is to provide for the receipt and preparation for processing of homogeneous and heterogeneous solids and homogeneous liquids received from LLNL Hazardous Waste Management. This includes processing the incoming combustible solids waste/surrogate items and combustible liquid waste/surrogate into a form required by the MSO demonstration. The decontamination system provides necessary equipment to ensure materials/containers can be safely transferred out of the facility. FP provides the management, system analysis and support, design (Title II, III) engineering, procurement, installation of FP equipment, Title III inspection, and acceptance test procedures (ATP).

\section{FY97 Plan}

Final design of the FP system was accomplished in September 1996 which included the specifications for the sorting, shredding, pelletizing, centrifuging and radiation detection equipment and enclosures. The design of the local instrumentation and control system will be completed in concert with the FFM system in FY98, as these two systems will share the same workstation. For this effort, most of the original requirements for conventional feed preparation no longer exist. For example, there will be no drum washers or equipment decontamination enclosure, just an area where swipes can be taken and limited decontamination of the outside surface of the container is accomplished. Also, there will be no gas monitoring of drums either for explosives or tritium as it is assumed all incoming waste containers from HWM will be fully characterized as to container contents. The only effort in FY97 will be to receive the equipment that was ordered.

\section{Budget}

FY97 Spending profile (\$K, CENRTC) (Receipt of Equipment only)

\begin{tabular}{|c|c|c|c|c|c|c|c|c|c|c|c|c|c|}
\hline & Ot & Nov & Dec & Jan & Feb & Mar & Apr & May & Jun & Jul & Aug & Sep & Total \\
\hline Revised Plan & 0 & 0 & 8.5 & 26.7 & 0 & 29.8 & 0 & 0 & 0 & 0 & 0 & 0 & 65.0 \\
\hline
\end{tabular}

Total Element Costs to Date (thru 9/96): $\$ 230 \mathrm{~K}$

Estimated Liens into FY98: None

\section{Major FY97 Procurements}

None 
FY98

Total Budget (\$K, CENRTC): $\quad$ \$54K

Total Procurements: None

\section{Milestones and Markers}

ID No. Milestone/Marker

Scheduled

E142-4 Complete all other equipment specifications and orders Date

E142-5

Complete local control design

Nov 98

E142-6

Begin assembly/staging in B292

Dec 98

E142-7

Checkout/Testing Complete

Jan 98

Jul 98 


\section{WBS Element 1.4.2.2 Telerobotics Sorting}

\section{Task Description}

The principal objective of the rebaselined Telerobotics Sorting (TRS) system within Solids Feed Prep is to demonstrate an engineering prototype telerobotic sorting and characterization system and evaluate its applicability to sites across the DOE complex. In a deployed system, TRS would interface with SFP container receiving and conventional size reduction and segregation equipment and replaces manual (hands-on) sorting and container handling operations in the potentially contaminated process room. TRS primary functions include drum movement; waste characterization; segregation of the incoming waste stream into bulk streams containing predominantly organic solids, heterogeneous solids, homogeneous inorganic solids and metals, and liquids not previously identified; and repackaging of reject materials. TRS provides the management, system analysis and support, design (Title I, II) engineering, procurement, installation of TRS prototype equipment. TRS includes both equipment and systems integration.

\section{FY97 Plan}

The Telerobotics Sorting element is complete. No FY97-98 activities.

\section{Budget}

FY97 Spending profile (\$K, CENRTC) (Receipt of Equipment only)

\begin{tabular}{|l|c|c|c|c|c|c|c|c|c|c|c|c|c|}
\hline & Odt & Nov & Dec & Jan & Feb & Mar & Apr & May & Jun & Jul & Aug & Sep & Total \\
\hline Revised Plan & 99.9 & 0 & 0 & 0 & 0 & 0 & 0 & 0 & 0 & 0 & 0 & 0 & 99.9 \\
\hline
\end{tabular}

Total Element Costs to Date (thru 9/96): $\$ 1544 \mathrm{~K}$.

Estimated Liens into FY98: None

Major FY97 Procurements

None

FY98

Total Budget (\$K, CENRTC): $\quad$ \$0K

Total Procurements: None

Milestones and Markers

ID No. Milestone/Marker

Scheduled

None No activity




\section{WBS Element 1.4.3. Liquids Feed Preparation}

\section{Task Description}

The principal objective of the Liquids Feed Preparation system is to provide for the receipt, characterization, preparation for processing, and handling of homogeneous and heterogeneous liquids and solids/liquids mixtures received from storage and other processes in the facility. This includes segregating the incoming waste stream into aqueous with Trimsol, chlorinated organic liquids, oils, solvents, and scintillation cocktails. Liquids Feed Preparation provides the management, system analysis and support, design (Title I, II, III) engineering, procurement, installation of Liquids Feed Preparation equipment, Title III inspection, and acceptance test procedures (ATP). Liquids Feed Preparation includes both liquids feed preparation equipment and systems integration.

\section{FY97 Plan}

This element is closed for the reduced scope project and critical activities are included in WBS 1.4.2, Feed Preparation.

\section{Budget}

FY97 Spending profile (\$K, CENRTC)

\begin{tabular}{|c|c|c|c|c|c|c|c|c|c|c|c|c|c|}
\hline & Ot & Nov & Dec & Jan & Feb & Mar & Apr & MGy & Jun & Jul & Aug & Sep & Total \\
\hline Revised Plan & 0 & 0 & 0 & 0 & 0 & 0 & 0 & 0 & 0 & 0 & 0 & 0 & 0 \\
\hline
\end{tabular}

Total Element Costs to Date (thru 9/96): \$433 K.

Estimated Liens into FY98: None

Major FY97 Procurements

None

FY98

Total Budget (\$K, CENRTC): $\quad$ \$0K

Total Procurements: None

Milestones and Markers

ID No. Milestone/Marker

Scheduled

None No activity




\section{WBS Element 1.5.1. Mediated Electrochemical Oxidation}

\section{Task Description}

The principal objective of Mediated Electrochemical Oxidation (MEO) system is to receive appropriately characterized mixed waste streams and completely convert the organic portions to $\mathrm{CO}_{2}$ and water, to recycle acid and silver, and to remove ash containing the radioactive constituents. The MEO element provides the management, system analysis and support, design (Title I, II, III) engineering, procurement, and installation of the MEO equipment, Title III inspection, and acceptance test procedures (ATP) covering both equipment and system integration activities.

FY97 Plan

This task has been closed out per DOE guidance. No FY97/FY98 activities

\section{Budget}

FY97 Spending profile (\$K, CENRTC)

\begin{tabular}{|c|c|c|c|c|c|c|c|c|c|c|c|c|c|}
\hline & Ot & Nov & Dec & Jan & Feb & Mar & Apr & May & Jun & Jul & Aug & Sep & Total \\
\hline Revised Plan & 0 & 0 & 0 & 0 & 0 & 0 & 0 & 0 & 0 & 0 & 0 & 0 & 0 \\
\hline
\end{tabular}

Total Element Costs to Date (thru 9/96): $\$ 1445 \mathrm{~K}$

Estimated Liens into FY98: None

\section{Major FY97 Procurements}

None

\section{FY98}

Total Budget (\$K, CENRTC): $\quad$ \$OK

Total Procurements: None

Milestones and Markers

ID No. Milestone/Marker Date

None No activity




\section{WBS Element 1.5.2. Molten Salt Oxidation}

\section{Task Description}

The principal objectives of Molten Salt Oxidation (MSO) are to receive appropriately characterized mixed waste streams and completely convert the organic portions to $\mathrm{CO}_{2}$ and water, manage the offgas, and to recycle/process the spent salt (including collection of radioactive and toxic constituents). The MSO project element provides the management, system analysis and support, design (Title I, II, III) engineering, procurement, and installation of the MSO equipment, Title III inspection, and acceptance test procedures (ATP) covering both equipment and system integration activities.

\section{FY97 Plan}

This plan provides for the design, construction and check out of a MSO system including offgas and salt recycle.

A configuration design will be generated followed by a review which will freeze and control the design. Final design will be completed. Equipment and material will be staged until assembly begins. The system will be modular to allow for easy transport from the staging area to B-292 where final assembly and installation will take place. All components and systems will be checked out in anticipation of operation.

\section{Budget}

FY97 Spending profile (\$K, CENRTC)

\begin{tabular}{|c|c|c|c|c|c|c|c|c|c|c|c|c|c|}
\hline & Ot & Nov & Dec & Jan & Feb & Mar & Apr & May & Jun & Jul & Aug & Sep & Total \\
\hline Revised Plan & 214.8 & 217.4 & 243.6 & 587.4 & 296.9 & 108.7 & 170.2 & 103.8 & 91.2 & 86.6 & 81.7 & 81.7 & 2284 \\
\hline
\end{tabular}

Total Element Costs to Date (thru 9/96): \$4231 K

Estimated Liens into FY98: None

Major FY97 Procurements

None

\section{FY98}

Total Budget (\$K, CENRTC): $\quad$ \$OK

Total Procurements: None 


\section{Milestones and Markers}

ID No.

Milestone/Marker

Scheduled

E152-3 Final design complete

Date

E152-4 Start move to B-292

Dec 96

E152-5

Staging complete

Apr 97

E152-6

Operational review

Jun 97

E152-7

System ready for operation

Jul 97

Aug 97 


\section{WBS Element 1.5.3. Wet Oxidation}

\section{Task Description}

The principal objective of Wet Oxidation (WOX) is to demonstrate treatment of organic mixed wastes using a wet oxidation process to convert the organic portions to $\mathrm{CO}_{2}$, water, and inorganic ions, leaving ash, salts, metals, and radionuclides in a residual solution/slurry. The WOX Project element provides the management, system analysis and support, design (Title I, II, III) engineering, procurement, and installation of the WOX equipment, Title III inspection, and acceptance test procedures (ATP) covering both equipment and system integration activities.

\section{FY97 Plan}

This task has been closed out per DOE guidance. No FY97/FY98 activities.

\section{Budget}

FY97 Spending profile (\$K, CENRTC)

\begin{tabular}{|c|c|c|c|c|c|c|c|c|c|c|c|c|c|}
\hline & Ot & Now & Dec & Jan & Feb & Mar & Apr & May & Jun & Jul & Aug & Sep & Total \\
\hline Revised Plan & 0 & 0 & 0 & 0 & 0 & 0 & 0 & 0 & 0 & 0 & 0 & 0 & 0 \\
\hline
\end{tabular}

Total Element Costs to Date (thru 9/96): $\$ 99 \mathrm{~K}$.

Estimated Liens into FY98: None

Major FY97 Procurements

None

FY98

Total Budget (\$K, CENRTC): $\quad$ \$OK

Total Procurements: None

Milestones and Markers

ID No. Milestone/Marker Date

None No activity




\section{WBS Element 1.5.4. UV Photolysis}

\section{Task Description}

The principal objective of UV Photolysis (UVP) is to demonstrate ultravioletdriven treatment of the hazardous and toxic organic constituents in the condensate from the Wet Oxidation process (WBS 1.5.3) to produce a sewerable water stream. The UVP Project element provides the management, system analysis and support, design (Title I, II, III) engineering, procurement, and installation of the UVP equipment, Title III inspection, and acceptance test procedures (ATP) covering both equipment and system integration activities.

\section{FY97 Plan}

This task has been closed out per DOE guidance. No FY97/FY98 activities.

\section{Budget}

FY97 Spending profile (\$K, CENRTC)

\begin{tabular}{|c|c|c|c|c|c|c|c|c|c|c|c|c|c|}
\hline & Ott & Nov & Dec & an & Feb & Mar & Apr & May & Jun & Jul & Aug & Sep & Total \\
\hline Revised Plan & 0 & 0 & 0 & 0 & 0 & 0 & 0 & 0 & 0 & 0 & 0 & 0 & 0 \\
\hline
\end{tabular}

Total Element Costs to Date (thru 9/96): $\$ 24 \mathrm{~K}$.

Estimated Liens into FY98: None

Major FY97 Procurements

None

FY98

Total Budget (\$K, CENRTC): $\quad \$ 0 \mathrm{~K}$

Total Procurements: None

Milestones and Markers

ID No. Milestone/Marker

Scheduled

None No activity




\section{WBS Element 1.5.5. Experimental Off-Gas}

\section{Task Description}

The principal objective of the Experimental Off-Gas Treatment (XOGT) element is to demonstrate advanced, more effective off-gas treatment technologies that minimize secondary waste. These are improved selective catalytic reduction (SCR) of $\mathrm{NO}_{x}$ to nitrogen in gaseous phase, acidic urea DeNO $x$ scrubbing, and advanced metal filters. The second objective is to demonstrate feasibility and effectiveness of off-gas treatment at or near to the source of the gas where the treatment can be tailored to that specific source. The XOGT project element provides the management, system analysis and support, design (Title I, II, III) engineering, procurement, and installation of XOGT equipment, Title III inspection, and acceptance test procedures (ATP) covering both equipment and system integration activities. The XOGT will be backed by the facility off-gas system.

\section{FY97 Plan}

This task has been closed out per DOE guidance. No FY97/FY97 activities.

\section{Budget}

FY97 Spending profile (\$K, CENRTC)

\begin{tabular}{|c|c|c|c|c|c|c|c|c|c|c|c|c|c|}
\hline & Ot & Nov & Dec & Jan & Feb & Mar & Apr & May & Jun & Jul & Aug & Sep & Total \\
\hline Revised Plan & 0 & 0 & 0 & 0 & 0 & 0 & 0 & 0 & 0 & 0 & 0 & 0 & 0 \\
\hline
\end{tabular}

Total Element Costs to Date (thru 9/96): $\$ 223 \mathrm{~K}$.

Estimated Liens into FY98: None

\section{Major FY97 Procurements}

None

\section{FY98}

Total Budget (\$K, CENRTC): \$OK

Total Procurements: None

Milestones and Markers

ID No. Milestone/Marker

None No activity


WBS Element 1.6.1. Process Transport and Storage

\section{Task Description}

The principal objective of the Process Transport and Storage (PTS) system is to collect, transfer, deposit, store and handle containers, discrete items, dry and wet bulk materials, slurries, and liquids. PTS provides management, system analysis and support, design (Title I, II, and III) engineering, procurement, installation of Process Support Systems equipment, Title III inspection, and acceptance test procedures (ATP). PTS includes both process transport and storage equipment and systems integration.

\section{FY97 Plan}

This task has been closed out per DOE guidance. No remaining FY97 or FY98 activities.

\section{Budget}

FY97 Spending profile (\$K, CENRTC)

\begin{tabular}{|c|c|c|c|c|c|c|c|c|c|c|c|c|c|}
\hline & Ott & Nov & Dec & an & Feb & Mar & Apr & May & Jun & Jul & Aug & Sep & Total \\
\hline Revised Plan & 0 & 0 & 0 & 0 & 0 & 0 & 0 & 0 & 0 & 0 & 0 & 0 & 0 \\
\hline
\end{tabular}

Total Element Costs to Date (thru 9/96): $\$ 115 \mathrm{~K}$.

Estimated Liens into FY98: None

Major FY97 Procurements

None

FY98

Total Budget (\$K, CENRTC): $\quad \$ 0 \mathrm{~K}$

Total Procurements: None

Milestones and Markers

ID No. Milestone/Marker

Scheduled

None No activity




\section{WBS Element 1.6.2. Process Diagnostic Services}

\section{Task Description}

The principal objective of the Process Diagnostic Services element is to provide chemical analysis support for process control and characterization, material control, and regulatory requirements. Process Diagnostic Services provides the management, system analysis and support, and design (Title II, III) engineering.

\section{FY97 Plan}

The Process Diagnostic Services element will provide a level of effort support to the Expedited MSO Demonstration in the area of on-line and at-line instrumentation for analytical data.

\section{Budget}

FY97 Spending profile (\$K, CENRTC)

\begin{tabular}{|l|c|c|c|c|c|c|c|c|c|c|c|c|c|}
\hline & Od & Nov & Dec & Jan & Feb & Mar & Apr & May & Jun & Jul & Aug & Sep & Total \\
\hline Revised Plan & 4.3 & 2.0 & 3.0 & 2.0 & 2.0 & 3.0 & 2.0 & 2.0 & 3.0 & 3.0 & 2.0 & 2.0 & 30.7 \\
\hline
\end{tabular}

Total Element Costs to Date (thru 9/96): \$205 K.

Estimated Liens into FY98: None

Major FY97 Procurements

None

FY98

Total Budget (\$K, CENRTC): $\quad$ \$OK

Total Procurements: None

ID No. Milestone/Marker Date

None Level of effort




\section{WBS Element 1.6.3. Water Treatment}

\section{Task Description}

Water Treatment is an integral part of treatment train demonstrations, continuing treatment of aqueous byproducts as part of demonstration tests to produce solid residuals suitable for Final Forms and fully treated water that meets treatment standards and sewer limits. The Water Treatment element provides the management, system analysis and support, design and engineering (Title I, II, III), procurement, and installation of the Water Treatment equipment necessary to demonstrate treatment trains, Title III inspection, and acceptance test procedures (ATP) covering both equipment and system integration activities.

\section{FY97 Plan}

This task has been close out per DOE guidance. No remaining FY97 or FY98 activities.

\section{Budget}

FY97 Spending profile (\$K, CENRTC)

\begin{tabular}{|c|c|c|c|c|c|c|c|c|c|c|c|c|c|}
\hline & Odt & Nov & Dec & Jan & Feb & Mar & Apr & May & Jun & Jul & Aug & Sep & Total \\
\hline Revised Plan & 0 & 0 & 0 & 0 & 0 & 0 & 0 & 0 & 0 & 0 & 0 & 0 & 0 \\
\hline
\end{tabular}

Total Element Costs to Date (thru 9/96): $\$ 96 \mathrm{~K}$.

Estimated Liens into FY98: None

Major FY97 Procurements

None

FY98

Total Budget (\$K, CENRTC): $\quad \$ 0 \mathrm{~K}$

Total Procurements: None

\section{Milestones and Markers}

ID No. Milestone/Marker

Scheduled

None No activity




\section{WBS Element 1.6.4. Final Forms}

\section{Task Description}

The Final Forms task is to immobilize the solid residues from the treatment of the mixed waste input streams by the primary process (MSO), and solid wastes resulting from secondary support processes that are integral to the primary treatment processes. The main task is immobilization of mineral residues in ceramic waste forms. Minor tasks are the immobilization of volatile inorganic solid (VIS) residues by microencapsulation in sulfur-polymer cement (SPC), and a "paper" design for microencapsulation of salt residues in polyethylene. FY97 Plan

Approximately $90 \%$ of procurements will be placed in FY97 using Management Reserve moneys. The rotary calciner will be installed as early as possible (Mar 97), so that the combined drying-calcining-granulation process can be developed. A primitive computer recipe-writer for ceramic formulations will be written in early FY98.

\section{Budget}

FY97 Spending profile (\$K, CENRTC)

\begin{tabular}{|l|c|c|c|c|c|c|c|c|c|c|c|c|c|}
\hline & Ot & Nov & Dec & an & Feb & Mar & Apr & May & Jun & Jul & Aug & Sep & Total \\
\hline Revised Plan & 19.6 & 10.6 & 10.5 & 0 & 0 & 0 & 0 & 0 & 0 & 0 & 0 & 0 & 40.8 \\
\hline $\begin{array}{l}\text { Management } \\
\text { Reserve }\end{array}$ & 0 & 0 & 0 & 9.7 & 9.7 & 187.1 & 19.3 & 19.3 & 19.3 & 9.7 & 9.7 & 53.4 & 337.0 \\
\hline
\end{tabular}

Total Element Costs to Date (thru 9/96): $\$ 1128 \mathrm{~K}$.

Estimated Liens into FY98: None

Major FY97 Procurements from MR

\begin{tabular}{|l|c|c|}
\hline \multicolumn{1}{|c|}{ Item } & $\begin{array}{c}\text { Estimated } \\
\text { Cost (\$K) }\end{array}$ & $\begin{array}{c}\text { Estimated } \\
\text { Order Date }\end{array}$ \\
\hline Pellet press & 88.0 & $12 / 1 / 96$ \\
\hline Rotary calciner & 99.0 & $12 / 1 / 96$ \\
\hline
\end{tabular}




\section{FY98}

Total Budget (\$K, CENRTC): $\quad \$ 419 \mathrm{~K}$

Total Procurements: None

Milestones and Markers

ID No. Milestone/Marker

Scheduled

E164-2.2 SPC waste form design complete Date

E164-2.3 Ceramic material design complete

Nov 96

E164-2.4 Recipe-writer complete

E164-2.5 Ceramic process design complete

Nov 96

E164-2 Final Forms designs complete

E164-3.2 FY97 procurements orders placed

Dec 98

Mar 98

Apr 98

E164-3 Most ( $95 \%$ ) of task equipment received

Sep 97

E164-4.1 Rotary calciner installed and operational for non-hazardous

Dec 97 operations

E164-4 All equipment installed and operational

Feb 98

E164-5 Documentation complete 
WBS Element 1.6.5. Supervisory Instrumentation and Control

\section{Task Description}

Supervisory Instrumentation and Control (I\&C) systems will be provided and integrated to demonstrate, test, and evaluate mixed-waste destruction technologies in a safe, environmentally acceptable, reliable, and cost-effective manner. I\&C systems provide the management, system analysis and support, design (Title I, II, III) engineering, procurement, equipment installation, Title III inspection, and acceptance test procedures (ATP) covering equipment and system integration activities for Facility database management, safety control, process I\&C standards, supervisory control, and ancillary systems and equipment including the instrumentation and equipment database, intercom communication, process and surveillance CCTV, cable and power distribution and grounding, and control room facilities.

\section{FY97 Plan}

This task has been closed out per DOE guidance. No FY97/FY98 activities

\section{Budget}

FY97 Spending profile (\$K, CENRTC)

\begin{tabular}{|c|c|c|c|c|c|c|c|c|c|c|c|c|c|}
\hline & Od & Nov & Dec & Jan & Feb & Mar & Apr & May & Jun & Jul & Aug & Sep & Total \\
\hline Revised Plan & 0 & 0 & 0 & 0 & 0 & 0 & 0 & 0 & 0 & 0 & 0 & 0 & 0 \\
\hline
\end{tabular}

Total Element Costs to Date (thru 9/96): $\$ 1266 \mathrm{~K}$.

Estimated Liens into FY98: None

\section{Major FY97 Procurements}

None

FY98

Total Budget (\$K, CENRTC): $\quad$ \$OK

Total Procurements: None

Milestones and Markers

ID No. Milestone/Marker

Scheduled

None No activity 


\section{Section 3.0 Cost Summary Reports}

Section

Description

Page

3.1 Revision 3.0 Cost Reconciliation

3.2 Project Cost Summary, Unescalated without MR

3.3 Project Cost Summary, Unescalated, with MR

3.4 Project Cost Summary, Escalated, with MR 


\section{Expedited Technology Demonstration Project Baseline Revision 3.0 \\ Unescalated Cost Reconciliation Summary at WBS Level 3}

\begin{tabular}{|c|c|c|c|c|c|c|c|}
\hline \multirow{2}{*}{\multicolumn{2}{|c|}{ WBS Elements }} & \multirow{3}{*}{$\begin{array}{c}\begin{array}{c}\text { Expended } \\
\text { thru } 9 / 96 \\
(\$ K)\end{array} \\
127 \\
\end{array}$} & \multicolumn{2}{|c|}{ Cost to Complete } & \multirow{3}{*}{$\begin{array}{l}\text { TOTAL } \\
(5 K) \\
153 \\
\end{array}$} & \multirow{3}{*}{$\begin{array}{c}\text { TOTAL } \\
\text { Prior Rev } \\
1.2 \text { (SK) } \\
255 \\
\end{array}$} & \multirow{3}{*}{$\begin{array}{l}\text { Cost Reconciliation \& Comments } \\
\text { Significant reduction in scope from Rev. } 1.2\end{array}$} \\
\hline & & & \multirow{2}{*}{$\begin{array}{c}\begin{array}{c}\text { Base } \\
(\$ K)\end{array} \\
26 \\
\end{array}$} & \multirow{2}{*}{$\begin{array}{c}\begin{array}{c}\text { Mngt Res } \\
\text { (SK) }\end{array} \\
0 \\
\end{array}$} & & & \\
\hline 1.1 .1 & QA & & & & & & \\
\hline 1.1 .2 & PSAR & 367 & 0 & 0 & 367 & 361 & PSAR revised for B292 during FY96 \\
\hline 1.1 .3 & Envir. Documen. & 386 & 10 & 0 & 395 & 776 & Significant reduction in scope from Rev. 1.2 \\
\hline 1.1 .4 & ES\&H & 391 & 35 & 0 & 426 & 803 & Significant reduction in scope from Rev. 1.2 \\
\hline 1.1 .5 & Prog. Support & 2,323 & 53 & 0 & 2.376 & 3,662 & Significant reduction in scope from Rev. 1.2 \\
\hline 1.1 .6 & Public Part. & 135 & 10 & 0 & 145 & 407 & Significant reduction in scope from Rev. 1.2 \\
\hline 1.2 .1 & Concept. Design & 2.235 & 0 & 0 & 2,235 & 2,235 & Activity completed in $\mathrm{FY} 94$ \\
\hline 1.2 .2 & Start-Up Mgmt. & 1 & 269 & 0 & 270 & 1,905 & Significant reduction in scope from Rev. 1.2 \\
\hline 1.2 .3 & Activation & 0 & 1,060 & 0 & 1,060 & 4,729 & Significant reduction in scope from Rev. 1.2 \\
\hline 1.3 .1 & Proj. Mgmt. & 1,333 & 596 & 0 & 1,928 & 3,577 & Significant reduction in scope from Rev. 1.2 \\
\hline 1.3 .2 & Proj. Control & 757 & 129 & 0 & 886 & 2,336 & Significant reduction in scope from Rev. 1.2 \\
\hline 1.3 .3 & Tech. Integration & 589 & 180 & $\underline{0}$ & 769 & 1,457 & Significant reduction in scope from Rev. 1.2 \\
\hline 1.4 .1 & Receiving \& Ship. & 128 & 0 & 0 & 128 & 415 & Activity closed for reduced scope project \\
\hline 1.4 .2 & Solids Feed Prep. & 1,774 & 217 & 0 & 1,991 & 5,926 & Significant reduction in scope from Rev. 1.2 \\
\hline 1.4 .3 & Liquids Feed Prep. & 433 & 0 & 0 & 433 & 2,069 & Activity closed for reduced scope project \\
\hline 1.5 .1 & MEO & 1.445 & 0 & 0 & 1,445 & 6,707 & Activity closed for reduced scope project \\
\hline 1.5 .2 & MSO & 4,231 & 2,284 & 0 & 6,515 & 9,352 & Significant reduction in scope from Rev. 1.2 \\
\hline 1.5 .3 & Wet Oxidaton & 99 & 0 & 0 & 99 & 99 & Activity closed in Revision 1.2 \\
\hline 1.5 .4 & UV Photolysis & 24 & 0 & 0 & 24 & 24 & Activity closed in Revision 1.2 \\
\hline 1.5 .5 & Expt. Off-Gas & 223 & 0 & 0 & 223 & 473 & Activity closed for reduced scope project \\
\hline 1.6.1 & Transp. \& Storage & 115 & $\underline{0}$ & 0 & 115 & 765 & Activity closed for reduced scope project \\
\hline 1.6 .2 & Process Diag. Ser. & 205 & 31 & 0 & 236 & 1,907 & Significant reduction in scope from Rev. 1.2 \\
\hline 1.6 .3 & Water Treatment & 96 & 0 & 0 & 96 & 1,194 & Activity closed for reduced scope project \\
\hline 1.6 .4 & Final Forms & 1.128 & 447 & 337 & 1,911 & 2,471 & Significant reduction in scope from Rev. 1.2 \\
\hline 1.6 .5 & Supervisory I\&C & 1,266 & 0 & 0 & 1,266 & 3,293 & Activity closed for reduced scope project \\
\hline & Other: LDRD & 342 & 0 & 0 & 342 & 342 & No longer charged LDRD \\
\hline & OPEX SUBTOTAL & 5,815 & 1,453 & 0 & 7,269 & 14,562 & \\
\hline & CENRTC SUBTOTAL & 14,337 & 3,893 & 337 & 18,567 & 42,980 & \\
\hline & PROJECT TOTAL & 20,152 & 5,346 & 337 & 25,836 & 57,542 & \\
\hline
\end{tabular}




\section{Expedited Technology Demonstration Project Baseline Revision 3.0 Cost Summary}

Unescalated, without Management Reserve

\begin{tabular}{|c|c|c|c|c|c|c|c|c|c|c|c|}
\hline WBS No. & Titio & & $\begin{array}{l}\text { Actual } \\
\text { FY93 }\end{array}$ & $\begin{array}{l}\text { Actual } \\
\text { FY94 }\end{array}$ & $\begin{array}{l}\text { Actual } \\
\text { FY95 }\end{array}$ & $\begin{array}{l}\text { Actual } \\
\text { FY96 }\end{array}$ & $\begin{array}{c}\text { FY97 } \\
\text { eatimate }\end{array}$ & $\begin{array}{c}\text { FY98 } \\
\text { extimate }\end{array}$ & $\begin{array}{c}\text { Cost To } \\
\text { Date }\end{array}$ & $\begin{array}{c}\text { Cost To } \\
\text { Complete }\end{array}$ & $\begin{array}{l}\text { TOTAL = } \\
\text { EAC SK }\end{array}$ \\
\hline 1.1) & & & 0 & 2687.8 & 775.2 & 265.9 & 55.0 & 79.7 & 3728.9 & 133.7 & 3862.7 \\
\hline 1.1 .1 & QOA & 0 & $x^{2} x^{2 x-3 y}$ & 1052 & $215.9 \times$ & $5.5 \times$ & 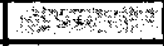 & $26.2^{2}$ & 126.6 & 26.2 & 152.8 \\
\hline \multirow[t]{3}{*}{1.1 .2} & PSAR & & 0 & 341.9 & 25 & 0.0 & 0.0 & 0.0 & 366.9 & 0.0 & 366.9 \\
\hline & PSARNE & 0 & -2 & 341.9 & 9.9 & 4,5458 & ( & (1) & 351.8 & 0.0 & 351.8 \\
\hline & PSARUCE & 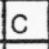 & ב3 & 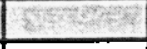 & 15.1 & 0.0 & 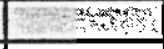 & nts? & 15.1 & 0.0 & 15.1 \\
\hline \multirow[t]{3}{*}{1.1 .3} & NEPAVCEQA & & 0 & 189.7 & 190.4 & 5.8 & 9.6 & 0.0 & 385.9 & 9.6 & 395.5 \\
\hline & NEPA(\&permit<95) & 0 & हिता & 189.7 & 61.4 & 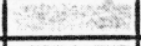 & 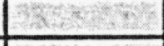 & 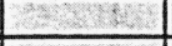 & 251.1 & 0.0 & 251.1 \\
\hline & Permits & $c$ & 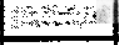 & 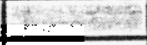 & 129 & 5.8 & 9.6 & 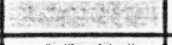 & 134.8 & 9.6 & 144.4 \\
\hline 1.1 .4 & ES\&H & 0 & + & $\begin{array}{r}135.9 \\
\end{array}$ & 142.7 & 112.7 & $17.5 \times ?$ & $\begin{array}{r}77.5 \\
\end{array}$ & 391.4 & 35.0 & 426.4 \\
\hline \multirow[t]{2}{*}{1.1 .5} & Prog. Support & 0 & 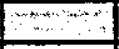 & 1903.7 & 309.8 & 109.6 & 21.4 & 31.9 & 2323.1 & 53.3 & 2376.4 \\
\hline & MA, CO, etc. & 0 & 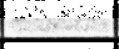 & 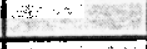 & 4 & 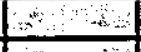 & 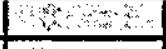 & n, & 0.0 & 0.0 & \\
\hline \multirow[t]{2}{*}{1.1 .6} & Public Part. & 0 & $3<<$ & 11.4 & 0.1 .4 & 32.2 & 6.5 & $3.1 \%$ & 135.0 & 9.6 & 144.7 \\
\hline & & & & & & & & & & & \\
\hline \multirow[t]{2}{*}{1.2} & & & 483 & 1753.9 & -1.6 & 0.9 & 123.8 & 1205.4 & 2236.2 & 1329.1 & 3565.4 \\
\hline & Concept. Design & 0 & $483^{\circ}$ & 1753.9 & -1.6 & 0.0 & 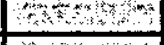 & mots & 2235.3 & 0.0 & 2235.3 \\
\hline 1.2 .2 & Start-up Mgmt & 0 & $y^{4}=4$ & as stont & 0 & 0.9 & $y_{0}+4$ & 8268.7 & 0.9 & 268.7 & 269.7 \\
\hline 1.2 .3 & Actlvation & 0 & ans? & $5 \quad 4$ & 80 & $0.0^{2}$ & 123.8 & 936.7 & 0.0 & 1060.4 & 1060.4 \\
\hline 1.3 & & & 0 & 431.8 & 1225.4 & 1022.0 & 707.0 & 197.5 & 2679.2 & 904.5 & 3583.7 \\
\hline \multirow[t]{2}{*}{1.3 .1} & Proj. Mgmt & c & $\begin{array}{ll} \\
\end{array}$ & 168.5 & 539.5 & 624.5 & 412.1 & 183.7 & 1332.6 & 595.8 & 1928.4 \\
\hline & $\mathrm{MR}, \mathrm{CO}$, etc. & c & 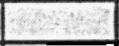 & 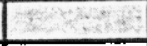 & 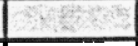 & 50 & 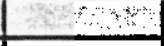 & का & 0.0 & 0.0 & \\
\hline 1.3 .2 & Proj. Control & $c$ & 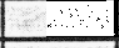 & 156.9 & 448.3 & 152.0 & 114.9 & 13.8 & 757.2 & 128.7 & 885.9 \\
\hline \multirow[t]{2}{*}{1.3 .3} & Tech. Integ. & c & & 106.4 & 237.6 & 245.5 & 180.0 & $-\alpha-x$ & 589.4 & 180.0 & 769.4 \\
\hline & & & & & & & & & & & \\
\hline \multirow{2}{*}{\begin{tabular}{r|}
1.4 \\
1.4 .1
\end{tabular}} & & & 0 & 331.7 & 1300.1 & 702.7 & 164.9 & 52.4 & 2334.5 & 217.3 & 2551.7 \\
\hline & Rec. \& Ship & $C$ & 3 & 30.4 & 81.6 & 15.7 & 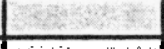 & $+30,50$ & 127.7 & 0.0 & 127.7 \\
\hline \multirow[t]{2}{*}{1.4 .2} & SFP-Conv. & C & & 15.8 & 108.6 & 105.2 & 65.0 & 52.4 & 229.6 & 117.4 & 347.0 \\
\hline & SFP-TRS & & & 142.6 & 867.1 & 534.2 & 99.9 & 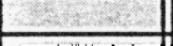 & 1543.9 & 99.9 & 1643.8 \\
\hline \multirow[t]{2}{*}{1.4 .3} & LFP & C & & 142.9 & 242.8 & 47.6 & 38 & +4 & 433.3 & 0.0 & 433.3 \\
\hline & & & & & & & & & & & \\
\hline \multicolumn{2}{|l|}{1.5} & & 0 & 1384.6 & 2827.5 & 1809.7 & 2284.2 & 0.0 & 6021.9 & 2284.2 & 8306.0 \\
\hline 1.5 .1 & MEO & C & & 716.8 & 721.1 & 7.3 & - & 65 & 1445.3 & 0.0 & 1445.3 \\
\hline 1.5 .2 & MSO & C & 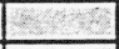 & 438.0 & 1990.7 & 1802.0 & 2284.2 & and & 4230.7 & 2284.2 & 6514.9 \\
\hline 1.5 .3 & wox & C & La: & 97.7 & 0.5 & 0.4 & ( & \begin{tabular}{|l|} 
\\
\end{tabular} & 98.6 & 0.0 & 98.6 \\
\hline 1.5 .4 & UNP & $C$ & & 24.0 & 0.3 & 0.0 & 28 & 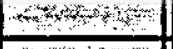 & 24.3 & 0.0 & 24.3 \\
\hline \multirow[t]{2}{*}{1.5 .5} & $X O G$ & $C$ & 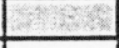 & 108.1 & 114.9 & 0.0 & $4 \sin$ & 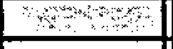 & 223.0 & 0.0 & 223.0 \\
\hline & & & & & & & & & & & \\
\hline \multicolumn{2}{|l|}{1.6} & & 0 & 938.3 & 1104.9 & 766.5 & 71.5 & 406.0 & 2809.7 & 477.5 & 3287.3 \\
\hline 1.6 .1 & Transp. \& Storage & $c$ & & 26.3 & 70 & 18.7 & & 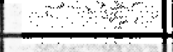 & 115.0 & 0.0 & 115.0 \\
\hline 1.6 .2 & Process Diag. Ser. & $c$ & 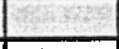 & 36.0 & 98.8 & 70.1 & 30.7 & 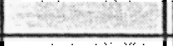 & 204.9 & 30.7 & 235.7 \\
\hline 1.6 .3 & Water Treat. & $c$ & , & 32.0 & 22.7 & 41.2 & $\therefore$ & -4 & 95.9 & 0.0 & 95.9 \\
\hline 1.6 .4 & Final Forms & $\mathrm{c}$ & & 367.0 & 391.8 & 368.8 & 40.8 & 406.0 & 1127.6 & 446.8 & 1574.3 \\
\hline \multirow[t]{5}{*}{1.6 .5} & Supv. 18C & $c$ & 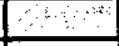 & 477.0 & 521.6 & 267.7 & & 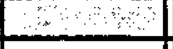 & 1266.3 & 0.0 & 1266.3 \\
\hline & & & & & & & & & & & \\
\hline & LOAD/CE & $c$ & 0 & 342 & 0 & lo & 0 & 0 & 342.0 & & 342.0 \\
\hline & & & & & & & & & & & \\
\hline & OPEX SUBTOTAL & 0 & 483 & 4441.7 & 629.5 & 261.1 & 169.2 & 1284.1 & 5815.3 & 1453.3 & 7268.6 \\
\hline \multicolumn{2}{|r|}{ CENRTC SUBTOTAL } & $\mathrm{c}$ & 0.0 & 3428.4 & 6602.0 & 4306.7 & 3237.2 & 655.8 & 14337.1 & 3893.0 & 18230.1 \\
\hline \multicolumn{2}{|c|}{ UNESC. PROJECT TOTAL } & & 483 & 7870.1 & 7231.5 & 4567.8 & 3406.4 & 1939.9 & $20+52$ & 5346 & 25499 \\
\hline
\end{tabular}




\section{Expedited Technology Demonstration Project Baseline Revision 3.0 Cost Summary}

Unescalated, with Management Reserve

\begin{tabular}{|c|c|c|c|c|c|c|c|c|c|c|c|}
\hline WBS No. & Titse & \multicolumn{2}{|c|}{$\mid \begin{array}{c}\text { Actual } \\
\text { FY93 }\end{array}$} & $\begin{array}{c}\text { Actual } \\
\text { FY94 }\end{array}$ & $\begin{array}{c}\text { Actual } \\
\text { FY95 } \\
\end{array}$ & $\begin{array}{l}\text { Actual } \\
\text { Fy96 }\end{array}$ & $\begin{array}{c}\text { FY97 } \\
\text { eatimate }\end{array}$ & $\begin{array}{c}\text { FY98 } \\
\text { estimate }\end{array}$ & $\begin{array}{c}\text { Cost To } \\
\text { Date }\end{array}$ & $\begin{array}{l}\text { Cost To } \\
\text { Complete }\end{array}$ & $\begin{array}{c}\text { TOTAL }= \\
\text { EAC SK }\end{array}$ \\
\hline 1.1 & & & 0 & 2687.8 & 775.2 & 265.9 & 55.0 & 78.7 & 3729 & 134 & 3863 \\
\hline 1.1 .1 & QA & 0 & 0 & 105 & 16 & $6 \cdot 6 \times$ & 0 & 26 & 127 & 26 & 153 \\
\hline \multirow[t]{3}{*}{1.1 .2} & PSAR & & 0 & 341.9 & 25 & 0.0 & 0.0 & 0.0 & 367 & 0 & 367 \\
\hline & PSAROE & 0 & 0 & 342 & 10 & 0 & -50 & 0 & 352 & of & 352 \\
\hline & PSARCE & C & 0 & 0 & 15 & 0 & 40 & 100 & 15 & o & 15 \\
\hline \multirow[t]{3}{*}{1.1 .3} & NEPACEOA & & 10 & 189.7 & 190.4 & 5.8 & 9.6 & 0.0 & 386 & 10 & 395 \\
\hline & NEPA (\&CEQA<95) & 0 & 0 & 190 & 61 & 00 & 0 & 00 & 251 & 0 & 251 \\
\hline & CEOAPermits & $\mathrm{C}$ & 0 & 0 & 129 & 66 & 10 & 0 & 135 & 10 & 144 \\
\hline 1.1 .4 & ES\&H & 0 & 0 & 136 & 143 & 113 & 18 & 18 & 391 & 35 & 426 \\
\hline \multirow[t]{2}{*}{1.1 .5} & Prog. Support & 0 & 0 & 1904 & 310 & $\therefore 110$ & 21 & 32 & 2323 & 53 & 2376 \\
\hline & $\mathrm{MA}, \mathrm{CO}$, etc. & 0 & 0 & 0 & 0 & 0 & 0 & 0 & of & of & 0 \\
\hline 1.1 .6 & Public Part. & 0 & 0 & 11 & 91 & 32 & $\begin{array}{r}7 \\
\end{array}$ & 3 & 135 & 10 & 145 \\
\hline \multicolumn{2}{|l|}{1.2} & & 483 & 1753.9 & -1.6 & 0.9 & 123.8 & 1205.4 & 2236 & 1329 & 3565 \\
\hline 1.2 .1 & Concept. Design & 0 & 483 & 1754 & -2 & 0 & 00 & 00 & 2235 & 의 & 2235 \\
\hline 1.2 .2 & Start-up Mgmt & 0 & 0 & 0 & 0 & 1 & $\mathbf{0}$ & 269 & 1 & 269 & 270 \\
\hline 1.2 .3 & Activation & 0 & 0 & 0 & 0 & 0 & 124 & 937 & 0 & 1060 & 1060 \\
\hline \multicolumn{2}{|l|}{1.3} & & 10 & 431.8 & 1225.4 & 1022.0 & 707.0 & 197.5 & 2679 & 904 & 3584 \\
\hline \multirow[t]{2}{*}{1.3 .1} & Proj. Mgmt & $\mathrm{C}$ & 0 & 169 & 540 & 625 & 412 & 184 & 1333 & 596 & 1928 \\
\hline & $\mathrm{MR}, \mathrm{CO}$, etc. & C & 0 & 0 & 0 & 0 & 30 & 0. & 요 & 의 & 0 \\
\hline 1.3 .2 & Proj. Control & C & 0 & 157 & 448 & 152 & 115 & 14 & 757 & 129 & 886 \\
\hline \multirow[t]{2}{*}{1.3 .3} & Tech. Integ. & $c$ & 0 & 106 & 238 & 245 & 180 & 0 & 589 & 180 & 769 \\
\hline & I & & & & & & & & & & \\
\hline \multicolumn{2}{|l|}{$1.4 \mid$} & & 10 & 331.7 & 1300.1 & 702.7 & 164.9 & 52.4 & 2334 & 217 & 2552 \\
\hline 1.4 .1 & Rec. \& Ship & $c$ & 0 & 30 & $\mathbf{8 2}$ & 16 & 0 & 0 & 128 & 의 & 128 \\
\hline \multirow[t]{2}{*}{1.4 .2} & SFP-Conv. & $c$ & 0 & 16 & 109 & 105 & 65 & 52 & 230 & 117 & 347 \\
\hline & SFP-TRS & & 0 & 143 & 867 & 534 & 100 & 0 & 1544 & 100 & 1644 \\
\hline \multirow[t]{2}{*}{1.4 .3} & LFP & $c$ & 0 & 143 & 243 & 48 & 0 & 0 & 433 & 의 & 433 \\
\hline & & & & & & & & & & & \\
\hline \multirow{2}{*}{$\frac{1.5}{1.5 .1}$} & & & 10 & 1384.6 & 2827.5 & 1809.7 & 2284.2 & 0.0 & 6022 & 2284 & 8306 \\
\hline & MEO & $c$ & 0 & 717 & 721 & 7 & $\therefore 0$ & 0 & 1445 & 이 & 1445 \\
\hline 1.5 .2 & $\mathrm{MSO}$ & $c$ & 0 & 438 & 1991 & 1802 & 2284 & 0 & 4231 & 2284 & 6515 \\
\hline 1.5 .3 & wox & $c$ & 0 & 98 & 1 & 0 & 30 & 0 & 99 & 0 & 99 \\
\hline 1.5 .4 & UNP & C & 0 & 24 & 0 & 0 & 00 & $\mathrm{O}$ & 24 & of & 24 \\
\hline 1.5 .5 & $x \in G$ & $C$ & 0 & 108 & 115 & 0 & 0 & 0 & 223 & 이 & 223 \\
\hline & & & & & & & & & & & \\
\hline 1.6 & & & 0 & 1938.3 & 1104.9 & 766.5 & 408.5 & 406.0 & 2810 & 815 & 3624 \\
\hline 1.6 .1 & Transo. \& Storage & C. & 0 & 26 & 70 & 19 & 0 & 0 & 115 & 의 & 115 \\
\hline 1.6 .2 & Process Diag. Ser. & C & 0 & 36 & $99^{\circ}$ & 70 & 31 & 0 & 205 & 31 & 236 \\
\hline 1.6 .3 & Water Treat. & $c$ & 0 & 32 & 23. & 41 & 0 & 0. & 96 & of & 96 \\
\hline 1.6 .4 & Final Forms & C & 0 & 367 & 392 & 369 & 378 & 406 & 1128 & 784 & 1911 \\
\hline 1.6 .5 & Supv. 1\&C & $\mathrm{C}$ & 0 & 477 & 522 & 268 & 0 & 0 & 1266 & 요 & 1266 \\
\hline & LLRD/CE & c & 10 & 342 & $\underline{0}$ & $\underline{0}$ & 0 & 10 & 342 & 아 & 342 \\
\hline & & & & & & & & & & & \\
\hline & OPEX SUBTOTAL & & 483 & 4442 & 630 & 261 & 169 & 1284 & 5815 & 1453 & 7269 \\
\hline & SENRTC SUBTOTAL & & 0 & 3428 & 6602 & 4307 & 3574 & 656 & 14337 & 4230 & 18567 \\
\hline UNESC & C. PROJECT TOTAL] & & 483 & 7870 & 7231.5 & 4567.8 & 3743.4 & 1939.9 & 20152 & 5683 & 25836 \\
\hline
\end{tabular}




\section{Expedited Technology Demonstration Project Baseline Revision 3.0 Cost Summary \\ Escalated, with Management Reserve}

\begin{tabular}{|c|c|c|c|c|c|c|c|c|c|c|c|}
\hline WBS No. & Title & & $\begin{array}{l}\text { Actual } \\
\text { FY93 }\end{array}$ & $\begin{array}{l}\text { Actual } \\
\text { FY94 }\end{array}$ & $\begin{array}{l}\text { Actual } \\
\text { Fy95 }\end{array}$ & $\begin{array}{l}\text { Actual } \\
\text { FY96 }\end{array}$ & $\begin{array}{c}\text { FY97 } \\
\text { estimate }\end{array}$ & $\begin{array}{c}\text { FY98 } \\
\text { estimate }\end{array}$ & $\begin{array}{c}\text { Cost To } \\
\text { Date }\end{array}$ & $\begin{array}{c}\text { Cost To } \\
\text { Complete }\end{array}$ & $\begin{array}{l}\text { TOTAL }= \\
\text { EAC SK }\end{array}$ \\
\hline 1.1 & & & 0 & 2687.8 & 775.2 & 265.9 & 55.0 & 81.1 & 3729 & 136 & 3865 \\
\hline 1.1 .1 & QA & 0 & 0 & 105 & 16 & 6 & 0 & 27 & 127 & 27 & 154 \\
\hline \multirow[t]{3}{*}{ 1.1.2 } & PSAR & & 0 & 341.9 & 25 & 0.0 & 0.0 & 0.0 & 367 & 0 & 367 \\
\hline & PSARIOE & 0 & 0 & 342 & 10 & 0 & $\begin{array}{l}0 \\
\end{array}$ & 0 & 352 & 0 & 352 \\
\hline & PSAR/CE & C & 0 & 0 & 15 & 0 & 0 & 0 & 15 & 0 & 15 \\
\hline \multirow[t]{3}{*}{1.1 .3} & NEPACEQA & & 0 & 189.7 & 190.4 & 5.8 & 9.6 & 0.0 & 386 & 10 & 395 \\
\hline & NEPA (\&CEQA<95) & 0 & 0 & 190 & 61 & 0 & 0 & 0 & 251 & 0 & 251 \\
\hline & CEQAVPermits & $\mathrm{C}$ & 0 & 0 & 129 & 6 & \begin{tabular}{|c|}
10 \\
\end{tabular} & 0 & 135 & 10 & 144 \\
\hline 1.1 .4 & ES\&H & 0 & 0 & 136 & 143 & 113 & 18 & 18 & 391 & 36 & 427 \\
\hline \multirow[t]{2}{*}{1.1 .5} & Prog. Support & 0 & 0 & 1904 & 310 & 110 & 21 & 33 & 2323 & 54 & 2377 \\
\hline & $\mathrm{MR}, \mathrm{CO}$, etc. & 0 & 0 & 0 & 0 & 0 & 0 & 0 & 0 & 0 & 0 \\
\hline 1.1 .6 & Public Part. & 0 & 0 & 11 & 91 & 32 & 7 & 3 & 135 & 10 & 145 \\
\hline \multicolumn{2}{|l|}{1.2} & & 483 & 1753.9 & -1.6 & 0.9 & 123.8 & 1241.6 & 2236 & 1365 & 3602 \\
\hline 1.2 .1 & Concept. Design & 0 & 483 & 1754 & -2 & 0 & 0 & 0 & 2235 & 0 & 2235 \\
\hline 1.2 .2 & Start-up Mgmt & 0 & 0 & 0 & 0 & $\begin{array}{r}1 \\
\end{array}$ & 0 & 277 & 1 & 277 & 278 \\
\hline 1.2 .3 & Activation & 0 & 0 & 0 & 0 & 0 & 124 & 965 & 0 & 1089 & 1089 \\
\hline \multirow[t]{3}{*}{1.3} & & & 0 & 431.8 & 1225.4 & 1022.0 & 707.0 & 203.4 & 2679 & 910 & 3590 \\
\hline & Proj. Mgmt & $\mathrm{C}$ & 0 & 169 & 540 & 625 & 412 & 189 & 1333 & 601 & 1934 \\
\hline & $\mathrm{MR}, \mathrm{CO}$, etc. & $\mathrm{C}$ & 0 & 0 & 0 & $\because 0$ & 0 & $0 \quad 0$ & 0 & 0 & 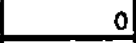 \\
\hline & Proj. Control & C & 0 & 157 & 448 & 152 & 115 & 140 & 757 & 129 & 886 \\
\hline 1.3 .3 & Tech. Integ. & C & 0 & 106 & 238 & 245 & 180 & 0 & 589 & 180 & 769 \\
\hline 1.4 & & & 10 & 331.7 & 1300.1 & 702.7 & 164.9 & 53.9 & 2334 & 219 & 2553 \\
\hline 1.4 .1 & Fec. \& Ship & C & 0 & 30 & 82 & 16 & 4tots 0 & 0 & 128 & 0 & 128 \\
\hline \multirow[t]{2}{*}{1.4 .2} & SFP-Conv. & C & $0 \%$ & 16 & 109 & 105 & $\begin{array}{r}465 \\
\end{array}$ & 54 & 230 & 119 & 349 \\
\hline & SFP-TRS & & 0 & 143 & 867 & 534 & +100 & monel & 1544 & 100 & 1644 \\
\hline 1.4 .3 & LFP & C & 0,0 & 143 & 243 & 48 & 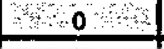 & 0 & 433 & 0 & 433 \\
\hline 1.5 & & & 10 & 1384.6 & 2827.5 & 1809.7 & 2284.2 & 0.0 & 6022 & 2284 & 8306 \\
\hline & MEO & $C$ & 0 & 717 & 721 & 7 & 0 & 0 & 1445 & 0 & 1445 \\
\hline 1.5 .2 & MSO & c & 0 & 438 & 1991 & 1802 & 2284 & 0 & 4231 & 2284 & 6515 \\
\hline 1.5 .3 & wox & $c$ & 0 & 98 & 1 & 0 & 0 & 0 & 99 & 0 & 99 \\
\hline 1.5 .4 & UNP & $c$ & 0 & $24^{8}$ & 0 & 0 & 0 & 0 & 24 & 0 & 24 \\
\hline 1.5 .5 & $x O G$ & C & 0 & 108 & 115 & 0 & 0 & 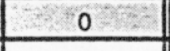 & 223 & 0 & 223 \\
\hline 1.6 & & & 0 & 938.3 & 1104.9 & 766.5 & 408.5 & 418.2 & 2810 & 827 & 3636 \\
\hline \multirow{2}{*}{\begin{tabular}{|l|}
1.6 .1 \\
1.6 .2
\end{tabular}} & Transo. \& Storage & $c$ & 0 & 26 & 70 & 19 & $\begin{array}{r}0 \% \\
\end{array}$ & 0 & 115 & 0 & 115 \\
\hline & Process Dlag. Ser. & c & 0 & 36 & 99 & 70 & 31 & 0 & 205 & 31 & 236 \\
\hline 1.6 .3 & Water Treat. & $c$ & 0 & 32 & 23 & 41 & 10 & $0 \quad 0$ & 96 & 0 & 96 \\
\hline 1.6 .4 & Final Forms & $c$ & 0 & 367 & 392 & 369 & 378 & 418 & 1128 & 796 & 1924 \\
\hline \multirow[t]{3}{*}{1.6 .5} & Supv. 18C & $c$ & 0 & 477 & 522 & 268 & 0 & 0 & 1266 & 0 & 1266 \\
\hline & & & & & & & & & 0 & 0 & \\
\hline & LDRD/CE & $c$ & 0 & 342 & & $\underline{0}$ & 0 & 10 & 342 & 0 & 342.0 \\
\hline & OPEX SUBTOTAL & & 483 & 4442 & 630 & 261 & 169 & 1323 & 5815 & 1492 & 7307 \\
\hline & ENRTC SUBTOTAL & & 0 & 3428 & 6602 & 4307 & 3574 & 676 & 14337 & 4250 & 18587 \\
\hline ESC. & C. PROJECT TOTAL & & 483 & 7870.1 & 7231.5 & 4567.8 & 3743.4 & 1998.1 & 20152 & 5742 & 25894 \\
\hline
\end{tabular}




\section{Appendix A}

LLNL Proposal for Project Reconfiguration

(letter to S. Cowan, dated May 2, 1996) 

May 2, 1996

Mr. Stephen P. Cowan

U.S. Department of Energy

1000 Independence Avenue SW

Routing Symbol EM-30

Washington, DC 20585

Dear Mr. Cowan:

Per your discussion with Jay Davis, LINL, and Jim Davis, DOE/OAK, on April 4, a plan has been developed to reconfigure LLNL's mixed waste program activities to align them more closely with DOE's current thrust on mixed waste. Since DOE has now been successful in engaging the private sector to take a stronger lead in treatment initiatives for most of its mixed waste, the need for a national pilot plant scale technology test bed becomes lower priority. Accordingly, work on the LINL Mixed Waste Management Facility (MWMIF) project can be suspended indefinitely.

At the time that the MWMF was originally proposed, many of the mixed waste streams at DOE sites across the complex were ill-defined and available treatment capability - public or private - did not exist. However, the project has been significantly delayed due to non-technical issues associated with funding availability and the loss of proposed LLNL facilities due to the expansion of United States Enrichment Corporation activities. Additionally, under the Federal Facilities Compliance Agreements addressing waste at DOE sites, stringent timetables have been established for developing and implementing site treatment plans. These factors have combined to limit the overall effectiveness of a centralized.demonstration facility to meet current DOE waste treatment requirements. Further, DOE issued a challenge to the private sector to take a lead position in the deployment of effective solutions to addressing mixed waste treament needs and this challenge largely has been met. DOE's major thrust is now to have the private sector lead in this area while providing supplemental efforts to address problematic waste streams and treatment limitations.

To address these problematic riche wastes and other special wastes around the DOE complex and across the country, a compelling need remains for innovative technologies. Our substantial work to date indicates that molten salt oxidation (MSO) would become the preferred technology for meeting many of these needs, if it is available. By building on our MSO R\&D and the MWMF project work that we have already completed, LINL can very cost efficiently accomplish an integrated system demonstration of MSO. This will 
provide an additional treatment technology to increase the robustness of DOE's group of technical options and will accomplish a key MWMF goal for the integrated demonstration of an alternative to incineration. It will also be beneficial to our efforts in the DOE DP and DoD programs at LLNL, which are developing high explosives, energetic materials, and hazardous waste treatment capabilities.

Toward this end, we have reconfigured LLNL's effort, selecting a more modest set of tasks. The revised plan will focus on evaluating the engineering, regulatory and economic viability of an integrated molten salt oxidation system, and in developing industrial capability to treat specific problematic wastes in the DOE complex. We will deploy and demonstrate all major system elements including: MSO primary unit with its secondary support components, e.g., salt recycle and off-gas, feed preparation, and final form stabilization of the process products - salt and mineral residues in polyethylene and ceramics, respectively. These systems may subsequently be transitioned to treatment as dictated by LLNL processing needs (pending permitting approvals). To reduce costs, equipment and instruments developed and procured for engineering development will be used to the extent possible. Further, while other project costs have been scaled back significantly, funding is maintained to continue activities with the regulators, industrial partners and the public.

The funding requirements for the expedited MSO demonstration for the reminder of FY96 through FY98 can be fully covered from the budget originally allocated to the MWMF in FY96. This will free outyear funding to address other priorities at DOE/OAK and LLNL. The table below shows the proposed funding for the system deployment and demonstrations including LLNL facility upgrade. Funding is included to complete the initial phase of demonstrations in the latter months of FY97 and continue demonstrations into FY98 with industrial support.

\begin{tabular}{|c|c|c|c|}
\hline Funding Source & $\begin{array}{l}\text { FY96 } \\
(\$ M)\end{array}$ & $\begin{array}{l}\text { FY97 } \\
(\$ M) \\
\end{array}$ & $\begin{array}{l}\text { FY98 } \\
(\text { SMI) } \\
\end{array}$ \\
\hline $\begin{array}{l}\text { DOE EM-30 } \\
\text { DOE DP (matching MOU) }\end{array}$ & $\begin{array}{l}5.8^{*} \\
0.63\end{array}$ & $\begin{array}{l}3.0 \\
0.6\end{array}$ & 2.0 \\
\hline DoD (matching MOU) & 0.63 & 0.6 & \\
\hline DoD & 0.3 & & \\
\hline Commercial support (est.) & 0.3 & 1.0 & 1.0 \\
\hline LLNL GPP & & 0.7 & \\
\hline
\end{tabular}


This revised plan coordinates activities from a number of funding sources and integrates various mission elements. For waste management applications, hazardous waste and mixed waste treatment activities will take place in the integrated MSSO system to be deployed in Bldg. 292. For the DOEDP Program, integrated MSO demonstrations will focus on the destruction of high explosives. Destruction of energetic materials of interest to DoD customers has been demonstrated and is currently being transitioned to the DoD. Additional MSO demonstrations can support DoD interests for the destruction of hazardous waste as well as commercial and medical interests in hazardous and mixed waste treatment.

We believe this plan will provide an extremely valuable complement to other technologies currently being pursued for DOE EMI waste treatment needs. Additionally it will support DOE DP and DoD requirements for the destruction of high explosives and energetic materials and provide for mixed and hazardous waste treatment options outside of the DOE complex. It provides a very cost effective, high leverage investment for DOE EM. LLNL looks forward to working with you and your organization and the DOE Oakland office in carrying out this important initiative.

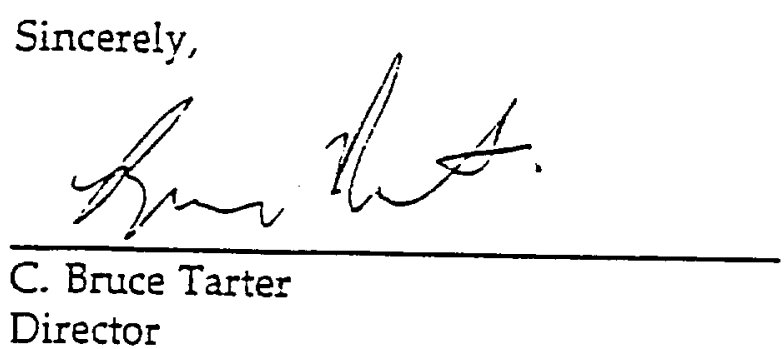





\section{Appendix B}

Revision 2.2 Guidance

(internal LLNL memo to MWMF Project, dated May 6, 1996) 



\author{
MIXED WASTE MANAGEMENT FACILITY \\ EXPEDITED TECHNOLOGY DEMONSTRATION
}

May 6, 1996

MWMIF 96-025

L-22152-01

\section{TO: $\quad$ Project Team}

FROM:

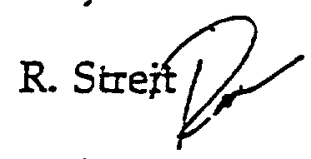

SUBJECT: Redirection Guidance for Expedited Technology Demonstration

\section{Introduction}

As we are all aware, the DOE funding situation has required that they reevaluate all of their programs with a focus on reducing cost while meeting the near term waste handling and treatment requirements. It appears that, while in the long term, the MWMIF will offer considerable benefit to the DOE and the' country, in the near term, adequate capacity for treating the majority DOE's current inventory of mixed waste will be available with existing technologies or by the deployment of technologies from projects currently in place. As a result, the MWMF Project will redirect its efforts toward an expedited technology demonstration of an integrated molten salt oxidation system (MSO)-from feed preparation to final forms.

At the time that the MWMIF was originally proposed, many of the mixed waste streams at DOE sites across the complex were ill-defined and available treatment capability-public or private-did not exist. However, the project has been significantiy delayed due to non-technical issues associated with funding availability and the loss of proposed LINL facilities (Bldg. 494). Further, DOE has issued a challenge to the private sector to take a lead position in the deployment of effective solutions to addressing mixed waste treatment needs, and this challenge largely has been met. DOE's major thrust is now to have the private sector lead in this area while providing supplemental efforts to address problematic waste streams and treatment limitations.

To address these problematic and niche wastes around the DOE complex and across the country, a compelling need remains for innovative technologies. Our effort indicates that MSO can effectively meet many of these needs. By building on our MSO R\&D and the MWMIF project work that we have already completed, we can very cost-efficiently accomplish an integrated system demonstation of MSO. This 
will provide an additional treatment technology to increase the robustness of DOE's group of technical options and will accomplish a key MWMF goal for the integrated demonstration of an alternative to incineration. It will also be beneficial to our efforts in the DOE DP and DoD programs at LLNL, which are developing high explosives, energetic materials, and hazardous waste treatment capabilities.

Toward this end, we are reconfiguring our effort, selecting a more modest set of tasks. The revised plan will focus on evaluating the engineering, regulatory and economic viability of an integrated MSO system, and in developing industrial capability to treat specific problematic wastes in the DOE complex. We will deploy and demonstrate all major system elements including: MSO primary unit with its secondary support components, e.g., salt recycle and off-gas, feed preparation, and final form stabilization of the process products. Since we will no longer be part of the DWTF complex, we have identified Bldg. 292 as the facility for the deployment of these systems.

The revised plan calls for completion of the initial phase of demonstrations in the latter months of FY97 and to continue demonstrations into FY98 with industrial support.

Because of the very tight time schedule and budget we will be under, it is critical that we move forward expeditiously and "together." I have asked Paul Densley to continue his role as the System Design Manager and oversee the Final Design and deployment effort. He will be coordinating the upgrades to Bldg. 292, and integrating all aspects of the hardware design.

The decision by DOE to redirect our efforts away from the national testbed was not an easy one. The long-term value of the MWMF Project has been recognized as the primary driver by DOE OAK and HQ. The effort that all of you have put into the project has been great. We have been redirected and rebaselined numerous times, and yet, we have been able to always produce a quality project. Staying focused on the job throughout all of the uncertainty has been exceptional. During the last two and a half years, we have turned this project into one of the best and most respected here at LLNL and the DOE. This has been a team effort that we can all be proud of. 


\section{Expedited Technologr}

- Demonstrate all major aspects of an MSO system, engineered for treatment facility operation (with exception of standard, off the shelf support systems)

- Deploy an integrated MSO system such that it can be transitioned to treatment of DOE mixed waste streams, and in particular, ELNL waste streams as required

- Coordinate demonstrations to support DOE's Defense Programs requirements (e.g., HE) and DoD (e.g., energetic materials and hazardous waste)

- Resolve conclusively the value of MSO as an integrated system for the treatment of mixed, radioactive and hazardous waste

- Demonstrate preparation of solid and liquid surrogate and mixed waste streams for treatment by MSO

- Demonstrate engineered features of molten salt system

- Demonstrate organic destruction efficiency for both solid and liquid feeds

- Demonstrate control and retention of toxic constituents

- Demonstrate separation of mineral residues from spent salt

- Demonstrate ability to clean and dry salt to meet LDR

- Demonstrate preparation and effectiveness of ceramic final forms

- Demonstrate encapsulation of salt residues for problematic salt streams

- Coordinate with industrial partiers who will take MSO out of the lab and into the private sector

\section{Planning Assumptions / Guidance}

- Systems to be in operation in FY97 in Bldg. 292

- Facility 292 Upgrade to be conducted in first quarter FY97, and completed by January 1, 1997

- Schedule guidance is shown in Attachment 1 showing a high level overview of the major project elements. Key milestones inciude:

Input received for Revised Plan 5/24/96

Configuration in Bldg. 292 Finalized $\quad 6 / 1 / 96$

Complete Revised Plan 6/1/96

Final design complete $\quad 10 / 1 / 96$

Beneficial occupancy of Bldg. $292 \quad 1 / 1 / 97$

Systems staged and ready for operation $7 / 15 / 97$

- Significant reduction in project management, controls, and reporting. Monthly reporting will be streamlines to "memo" form, and budget accountability, controls, and reporting will be the direct responsibility of the PEs 
- Attachment 2 delineates the budget guidance for completing this revised Project Plan. This is guidance, only, and should be used as such. It provides for a budget meeting the agreements with DOE and provides for key project design elements. To the extent possible, we are designing to cost, however, if there is concem that we cannot meet project demonstration goals or schedule, see me ASAP to discuss potential altematives (e.g., reduced scope, shifting of funds, etc.)

- Environmental documentation will be completed so as to allow us to complete GPP upgrades and stage in Bldg. 292 by January 1997

\section{Preparation of revised Plan Document}

A revised Project Plan will be completed. This is important to cleanly close off project elements which were part of the more global MWMF effort and to establish a budget starting point and scope for the remainder of the project. Using the format we have developed for the previous FY plans, we will develop a plan which encompasses 17 months-from May 1996 through September 1997. The activities for the five months in FY96 should be clearly delineated from those for FY97, as should the budget requirements. Laura will e-mail to the responsible individual the final FY96 Plan pages and the new revised plan template for updating. Attachment 3 is a copy of the new template. Your input MUST be returned to Laura by 5/24/96 for integration into the final document. 


\section{Soecific Guidance}

1.1.I Quality Assurance: QA activities have been reprogrammed to CENRTC. Minimal support identified in operations at end of FY97.

1.1.2 PSAR: Activity complete in FY95. FSAR will be funded from DWTF budget. No additional funding has been identified.

1.1.3 Environmental Documentation: Complete documentation required for operation in Bldg. 292 with surrogate feeds and actual waste within treatability study limits.

1.1.4 ES\&H: Effort will be on an as requested basis for reviews of design and documentation.

1.1.5 Program Support: Management functions covered under this element will be maintained at a minimum.

1.1.6 Public Participation: Public Participation will continue to support public interactions including National Review Panel, public meetings, and newsletters, however, at a significantly reduced funding level. This element will address interactions with DTSC for establishing Califomia Certification Program.

1.2.1 Conceptual Design: This is a completed element. All cost accounts have been closed.

1.2.2 / 1.2.3 Plant Start-up and Activation: Scope/budget of these elements will be reduced as a result of the reduced scope of the project. These activities will be focused on approvals for operations (e.g., FSP and OSPs) and operations training.

\subsection{1 / 1.3.2 / 1.3.3 Project Management / Project Control / Techrical Systems} Integration: Management functions covered under this element are largely levelof-effort and will be maintained at a minimum. A major component of this element is in the OFC charges for offices. This will be reduced by consolidating into one Trailer, T1877.

1.4.1 Receiving and Shipping: This element is closed for the reduced scope.

Receiving and shipping will be an operational function with space allocated in the high-bay area of B292 for temporary storage of materials

1.4.2 / 1.4.3 Feed Preparation: A minimum conventional feed preparation will be deployed to support the demonstiations of MSO. The system must be capable of 
preparing solid and liquid feeds of both surrogate and actual waste. Feeds will be prepared in a batch mode to support daily operations of the MSO primary system.

The demonstration feed preparation system elements is closed for the reduced scope. Funding will be included for close-out of activities or until effort is picked up by DWTF for incorporation into HWM future operations.

1.5.1 Mediated Electrochemical Oxidation: Deleted after Preliminary Design, System Design Description documentation complete.

1.5.2 Molten Salt Oxidation: This is a key element of the Expedited Technology Demonstration Project. A revised system design will be completed based on encompassing all elements of a treatment train including: feed distribution, primary reactor, offgas, and salt recycle systems. The system should demonstrate all key engineering and operation features required for final scale-up to plant size.

1.5.5 Experimental Offgas: This element is closed for the reduced scope.

1.6.1 Process Transport and Storage: This element is closed for the reduced scope.

1.6.2 Process Diagnostics Services: Effort will be on an as requested basis. Under the new scope, no new equipment will be procured for an analytical laboratory or LIMS system deployed.

1.6.3 Water Treatment: This element is closed for the reduced scope. Operations will employ use of HWM for disposition of all waste water from demonstrations.

1.6.4 Final Forms: This is a key element of the Expedited Technology Demonstration Project. The revised design effort should be directed to meeting the schedule/cost profile provided. The focus should be on ceramic final forms, however, back-up for salt polymer encapsulation should be included.

1.6.5 Supervisory Instrumentation and Control (SIC): This element is closed for the reduced scope. 


\section{Expedited Technology Demonstration Schedule}

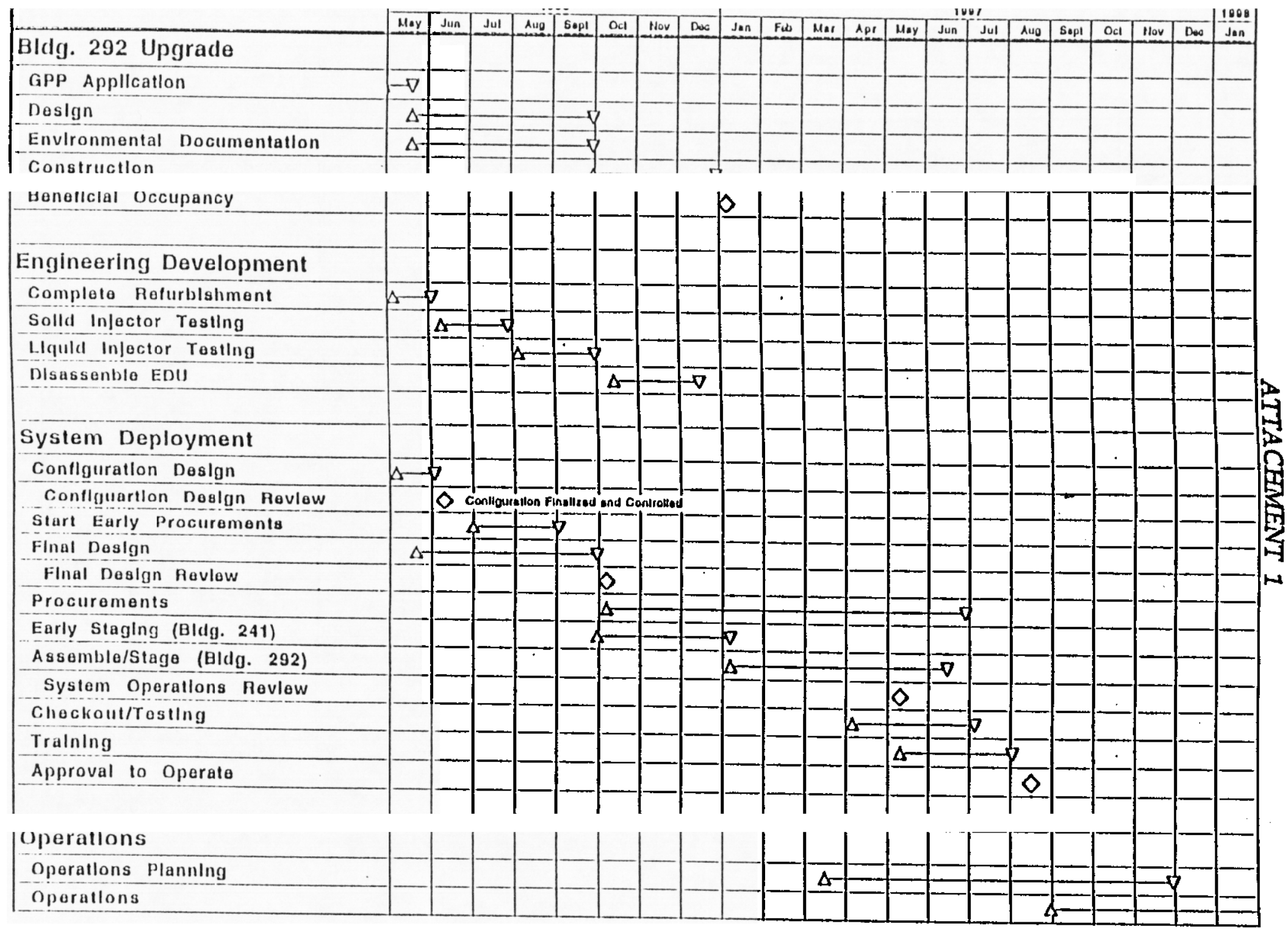




\begin{tabular}{|c|c|c|c|c|c|}
\hline SHEET 3 & $\begin{array}{l}\text { TOTAL Estimate } \\
\text { (Unsec, with MA) }\end{array}$ & (1) & $\begin{array}{c}\text { Total cost } \\
\text { thru Mar } 96 \\
\text { SK } \\
\end{array}$ & $\begin{array}{c}\text { FY96 } \\
\text { estimate } \\
\text { Apr-Sep } \\
\text { SK } \\
\end{array}$ & $\begin{array}{c}\begin{array}{c}\text { FY97 } \\
\text { estimate } \\
\text { SK }\end{array} \\
\end{array}$ \\
\hline 1.1 .1 & QA & 0 & 127 & 0 & 31 \\
\hline 1.1 .2 & PSAR & & 367 & 25 & 0 \\
\hline 1.1 .3 & NEPACEOA & & 385 & 30 & 16 \\
\hline 1.1 .4 & ESBH & 0 & 388 & 29 & 56 \\
\hline 1.1 .5 & Prog. Support & 0 & 2294 & 11 & 53 \\
\hline 1.1 .6 & Public Part. & 0 & 129 & 34 & 74 \\
\hline & ". & & & & \\
\hline 1.2 .1 & Concept. Design & 0 & 2235 & 0 & 0 \\
\hline 1.2.2 & Start-up Mgmt & 0 & 1 & 0 & 201 \\
\hline 1.2 .3 & Activation & 0 & 0 & 0 & 390 \\
\hline 1.3.1 & Proj. Mgmt & C & 1071 & 355 & 555 \\
\hline 1.3 .2 & Proj. Control & $\mathrm{C}$ & 723 & 50 & 60 \\
\hline 1.3 .3 & Tech. Integ. & C & 479 & 75 & 150 \\
\hline 1.4 .1 & Rec \& Ship & $c$ & 123 & 5 & 0 \\
\hline \multirow[t]{2}{*}{1.4 .2} & SFP-Canv. & c & 447 & 157 & 97 \\
\hline & SFPTRS & & 1010 & 75 & 0 \\
\hline 1.4 .3 & LPP & C & 433 & 5 & 0 \\
\hline 1.5.1 & MED & $c$ & 1441 & 0 & 0 \\
\hline 1.5 .2 & MSO & C & 3277 & 1817 & 1100 \\
\hline 1.5 .3 & wox & c & 99 & 0 & 0 \\
\hline 1.5.4 & UNP & $c$ & 24 & 0 & 0 \\
\hline 1.5 .5 & $x \in g$ & $c$ & 223 & 0 & 0 \\
\hline 1.6 .1 & Transp. \& Storage & $c$ & 108 & 3 & 0 \\
\hline 1.6 .2 & Anal. Lab. & c & 174 & 30 & 30 \\
\hline 1.6 .3 & Water Treat. & $c$ & 93 & 5 & 0 \\
\hline 1.6 .4 & Final Forms & c & 961 & 480 & 330 \\
\hline \multirow[t]{4}{*}{1.6 .5} & Supv. 18C & $\mathrm{C}$ & 1205 & 50 & $\underline{0}$ \\
\hline & & & 0 & & \\
\hline & OPEX SUETOTAL & & 5777 & 74 & 805 \\
\hline & CENATC SUBTOTAL & & 12382 & 3162 & 2338 \\
\hline
\end{tabular}




\section{ATTACHMENT 3}

\section{WBS Element $x \times x$. Your Element}

\section{Task Description}

This is the description for the WBS dictionary as modified, if necessary, to align with the revised project scope.

\section{FY96/97 Plan}

This paragraph should describe the elements to be completed in the last 5 months of FY96 and all of FY 97 to accomplish the task description described above, that is, how the work is to be performed.

\section{Budget}

FY96 Spending profile for remainder of FY (\$K, CENRTC)

\begin{tabular}{|l|l|l|l|l|l|l|}
\hline & Mhy & Jun & Jul & Aug & Sep & Total \\
\hline Revised Plan & & & & & & $x 0 x$ \\
\hline
\end{tabular}

FY97 Spending profile (\$K, CENRTC)

\begin{tabular}{|l|l|l|l|l|l|l|l|l|l|l|l|l|l|}
\hline & Oct & Nov & Dec & Jan & Feb & Mar & Apr & Why & Jur & Jul & Aug & Sep & Total \\
\hline Revised Plan & & & & & & & & & & & & & $\times 0 x$ \\
\hline
\end{tabular}

Total Element Costs to Date (thru 4/96): \$xckK.

Estimated Liens into FY97: SAIC Contract $\$ 23 \mathrm{~K}$

Major FY96 Procurements

\begin{tabular}{|l|c|c|}
\hline \multicolumn{1}{|c|}{ Item } & $\begin{array}{c}\text { Estimated } \\
\text { Cost (SK) }\end{array}$ & $\begin{array}{c}\text { Estimated } \\
\text { Order Date }\end{array}$ \\
\hline Widget $\mathrm{A}$ & 150.0 & $7 / 1 / 96$ \\
\hline (add rows as required) & & \\
\hline & & \\
\hline
\end{tabular}

Major FY97 Procurements

\begin{tabular}{|l|c|c|}
\hline \multicolumn{1}{|c|}{ Item } & $\begin{array}{c}\text { Estimated } \\
\text { Cost (SK) }\end{array}$ & $\begin{array}{c}\text { Estimated } \\
\text { Order Date }\end{array}$ \\
\hline Widget B & 150.0 & $7 / 1 / 97$ \\
\hline (add rows as required) & & \\
\hline & & \\
\hline
\end{tabular}




\section{Milestones and Markers}

ID No.

Milestone/Marker

Scheduled

LXCX-X Completed Wonderful Job

update these to meet new plan...make them realistic, important, and attainable...this will be our contract to the DOE if not ourselves! Limit yourselves to milestones reasonably distributed and on the order of 5-8. 


\section{Appendix C}

\section{DOE Approval letter}

(letter to J. T. Davis, dated June 6, 1996) 


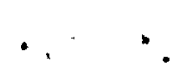




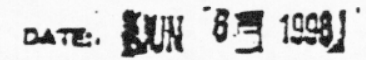

Rerir.to

$\triangle T$ TI $E M-30$

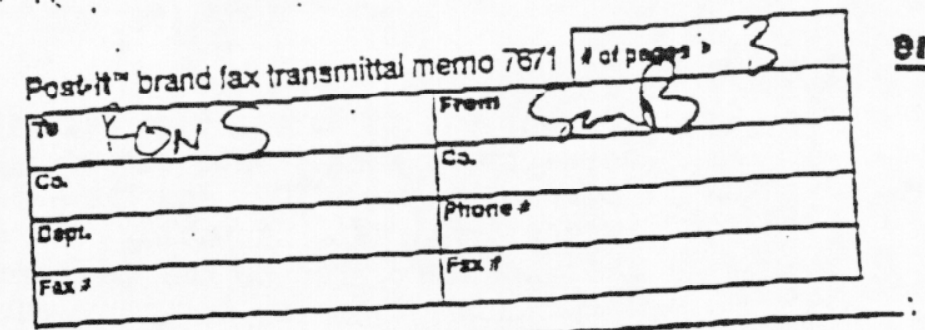

susiact Descope of the Hixed Wasto Management Factlity Project

Tor James T. Davis, Associata Managar for Environuental Managenent, Oakiland - Operations offica

The Offica of Wasta Management has recaived a wararandua from the Oepartent of Energy "Oakland Gperations Offies (DOE/ONK) out Ining an option whth would deseope the Mixed Wiste Manageant Facillty (winf). project and to use. the ranaining uncostad funds to exapiete. the development of Molton Salt Oxidation (HSO) as a ixed-waste treatwent option and initiata other Return. on Investrant/Mortgaga reduction projects. II-30 has chosen this option as. the anost appropiryate future caurse for thi Mhip project. The purpose of this momorandun is to outline the staps to be takea. to implement this option.

Ongoing changes. In DoE's mixed-wasts treatment strategy have requirad re-examination of the nned for a factlity to deapnstratie the treatneint of. low-lavel organie ufxed waste. . Mith was orfglnally idantified to be.a national test bed which could provide the technical basis for the traatment of Lawrenea' Liversore Nat ienal Laboratory (LLNL), DOE complex, and comercial low-level aixed organte wasta vithout thi use of theinerafion.

Sinca the incaption of this project, the DoE's national nixed-waste tratont stratagy has avolved in a new directon. The stratagy has changed toward prtvataly financad and operated trastwent fictlitfes with finitad denonstrations of new tochnologies. Deiays in the Mrif project and

- accalerated technology developent schedules haye meant that eany of the now tacinologies. necissary for treating the current backlog of wastes will be rasdy before the Minf can be brought on IYne. DoE's eurtant strategy is to. have the priyate sectior take. the lead in addressing mixid-yaste treatant inceds.

We still beffive. that the mir is a worthotle project. A centralized faell tiy could be an effective and consistant vay for the De to tast new tachnojogies. However, the changes in the treathant strategies now man the profect is no longer essential to reeting our traatwent goals. Wth funding tevels decining, wast give'first priorfty to those projects that will be raguired for. BM-30 to. complate its in sston, and tharafore, funding to the MWMF profect, relatad to the intagrated facility nust be discontinued. :This racanmerdation is cons istent with the rocomindation of the Hixed Haske Focus Araz (MFA): Thi Milf roviewed the continued need for the MHF project and conciuded that the need for capability to denenstrate treatment 27tenrnatives to incineration will only be needed on a imltod basts by. the time the HWMF is operational. This indted apolicability does not Justify the capital expenditure required. to desigm construct, and permit the hisf facijity. ionsequently, the WFA.reconmended that the funding for the Minf project should be discontinued. 


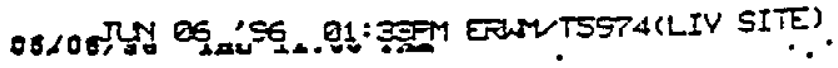

- Wo continue to have a high degrie of intarast in following timrough on oy dovelopment work in. nso technology by completting a deanstration unit. .0.

. Defensa Prograns (OP) and the Departatent of Defensa (DCO) are both interastad in HSO tachnology and are working on developinint effortes at LiKL. that are unralated to the Phif project. OP and DOo have expressed a willingness to share costs and developant efforts for continued deionstration of MSO. The willingness of DOE DP and $D O D$ to contribute funding for this aetivity desonstrates the potential of this technology (sae Table I in the Attactivent).

Aceordingly; by this ingorandum you are iuthorized to descope the hivf project by doloting all elements of the project except completing:a desonaţration of iso as a mixed-inste treatient optfon. The effort should focus on off gas, sait recyele, and final fornis treatwent as gart of an integrated dewonstration using sowe Lull wixed waste arid/or wasta from othor

$\therefore$ sttas. The work should. be completed by the end of FY98 and managed us a deoonstration project for apolied technology. Two tmportant goais of the

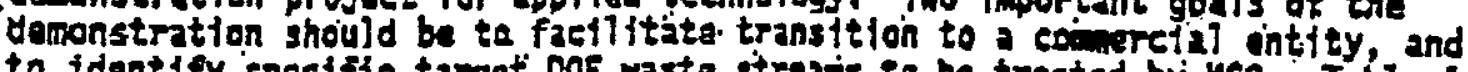
to identffy specifie targot $00 E$ waste streais to be trated by. uso. Tabie 1 gives a breakdown of funding that is expected by sodrce and by year: $A$ - detalled cost ind schedule' review stiould be porformed as soon as possible to validate the new plans.

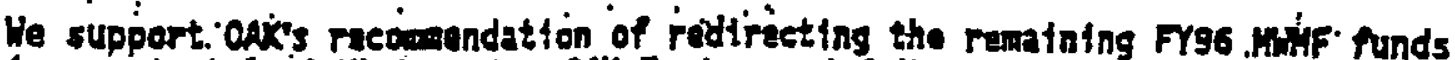
(2pproximately S5X) to other OKK Environental Managewent priprity projects such is legecy waste disposal or other raturn on investant inftiatives using a. corporate approceti. Funds that wll not have valitd work scope or be obligațed this fiscal year should be raturned: to Hoadquartars in a timely manner; to suppont other wi neẹds.

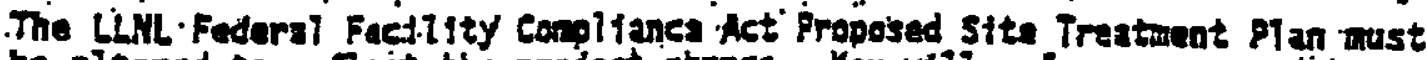
be altarad. to rafiect the project change. You will, of coursa, naed: to work wh your rogulator and other States and DOE.st tas as appropritate to: Identify a new pritiairy treatant option.

GIven the intarrelatienshlp between the Ducontamination and Wasta Tratant

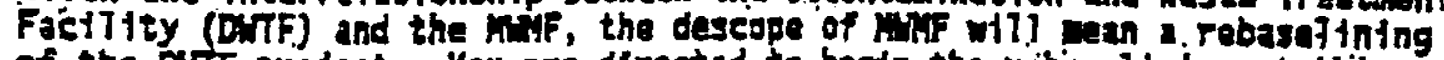
of the DWif project. You are diracted to begin the rebiselining at this tine in order to be complated prior to the new project.validation deadiline. of Ju7y 31, 1996.

If, you have anj questions, please eall. we or you uay call John héave bof iny staff at .301-903-7578.

Attxeçaneṇt

Staphen 'P. Cowan

Doputy Assistant Secratary for Haste Managenent Environciental Hanguent 
*."

TABLE 1.

BSO Annual Funding Requitreaents.

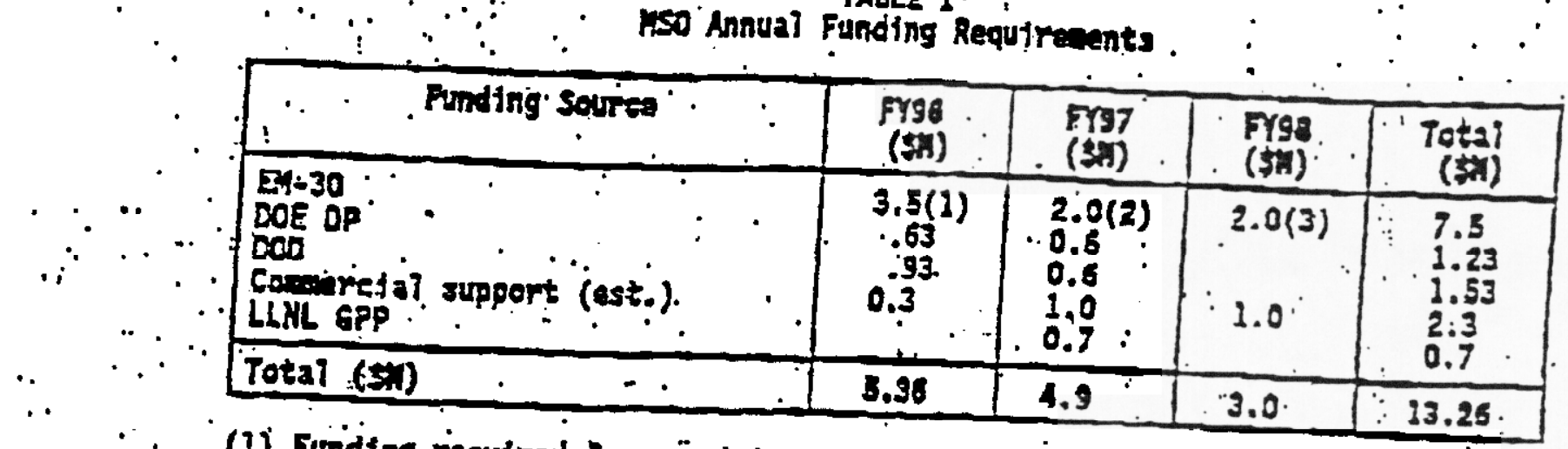

(1) Funding requirad for rënining FY, not total year funds.

(2) One-ting applied to:

(3) 52 . O4 requirame to demonstyation project.

Figr budget subinission. 



\section{Appendix D}

Project Baseline Revision Log 
$1, \cdots$ 
Revision Date: 10/96

Appendix D Project Baseline Revision Log

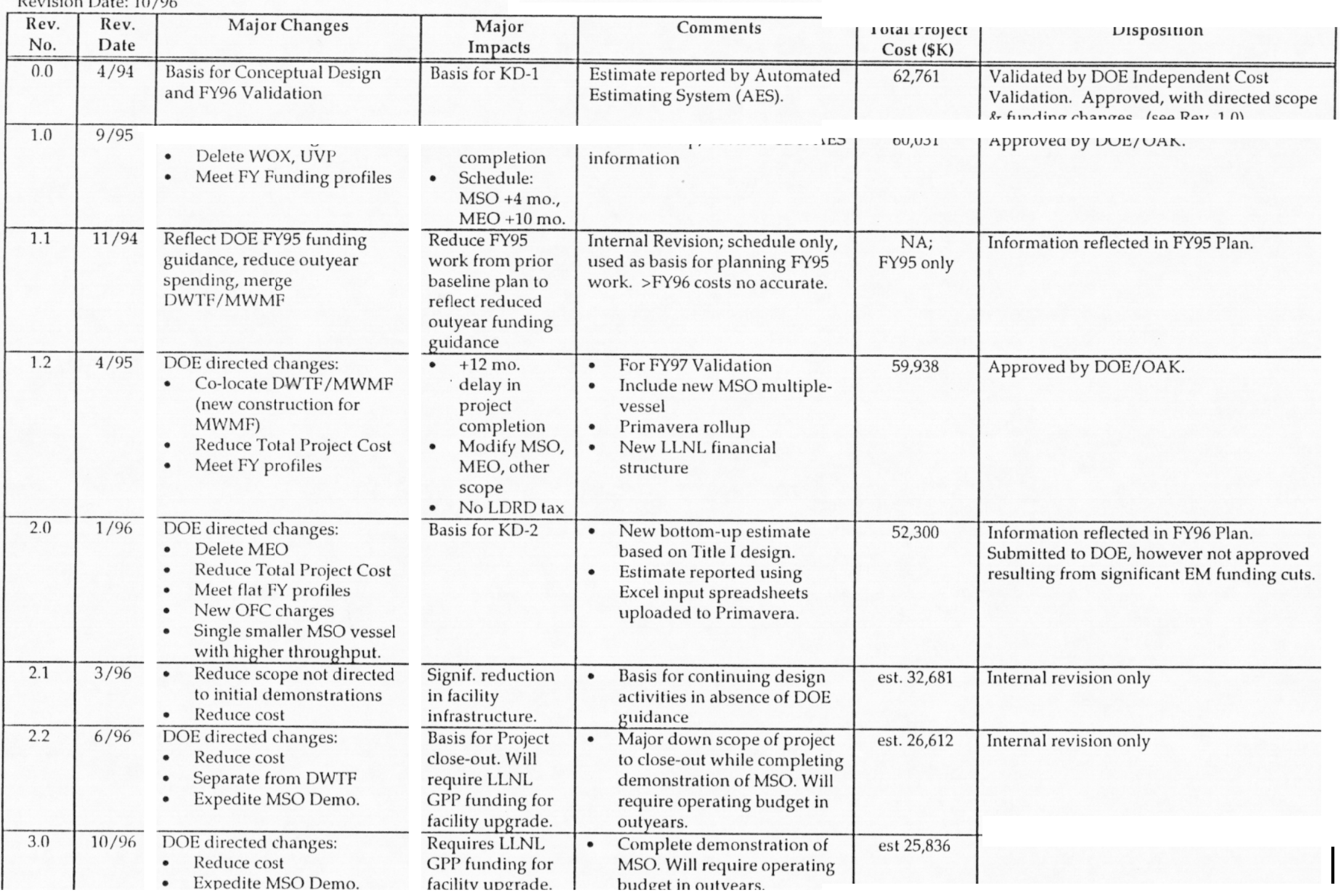



Appendix E

Revision 3.0 Milestone Log 



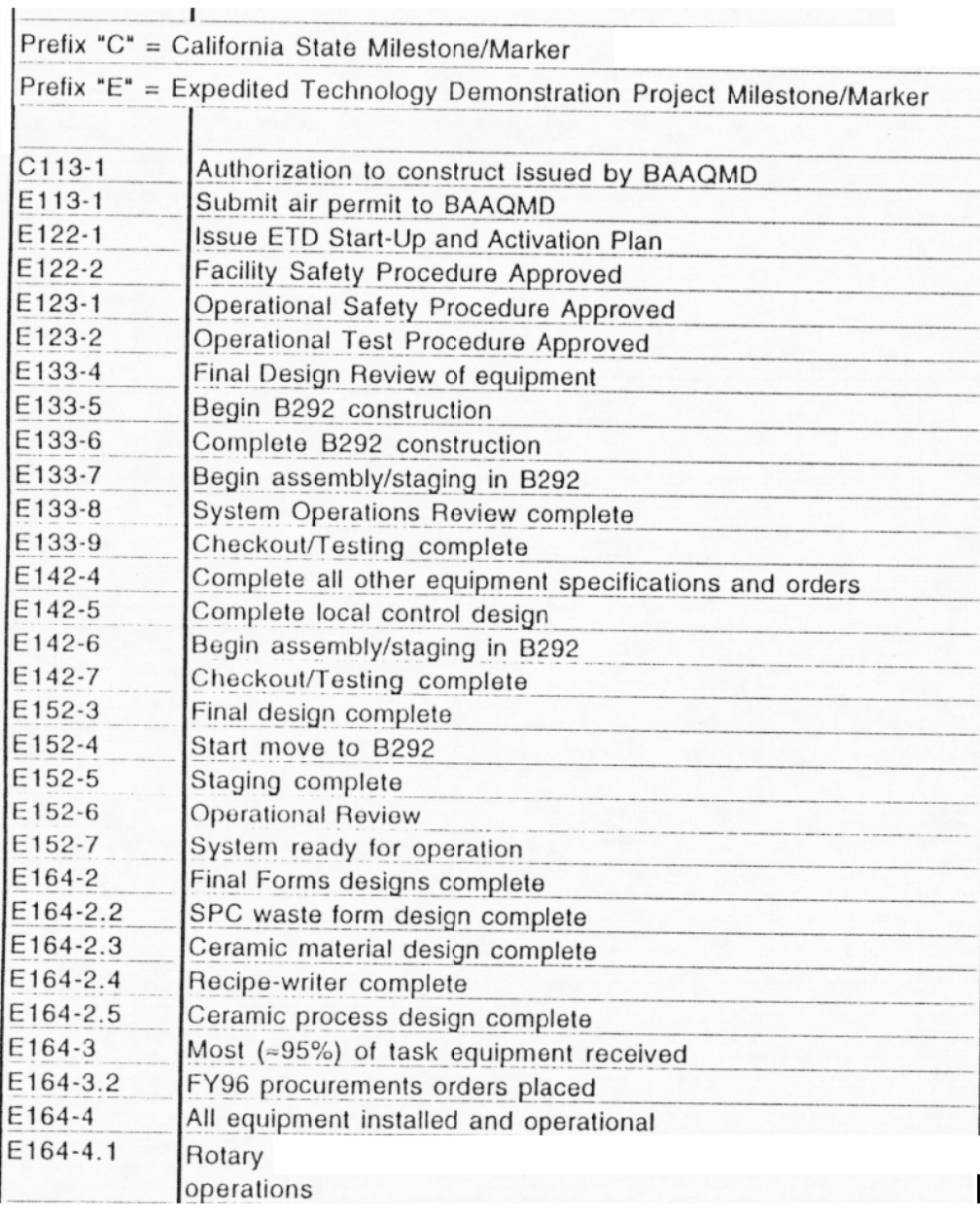

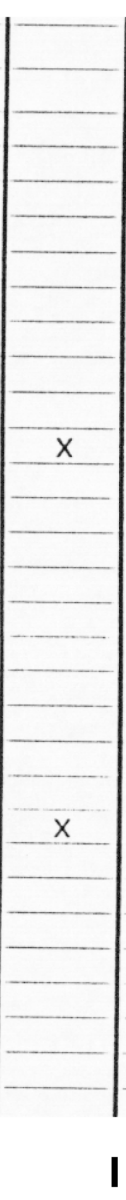

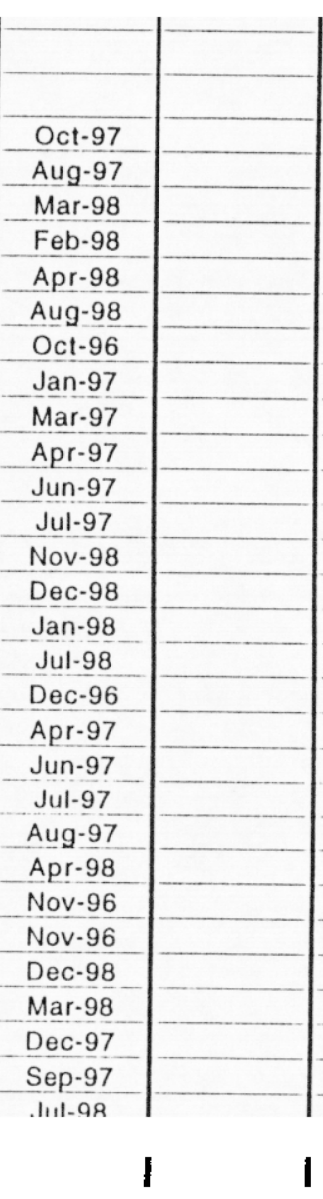

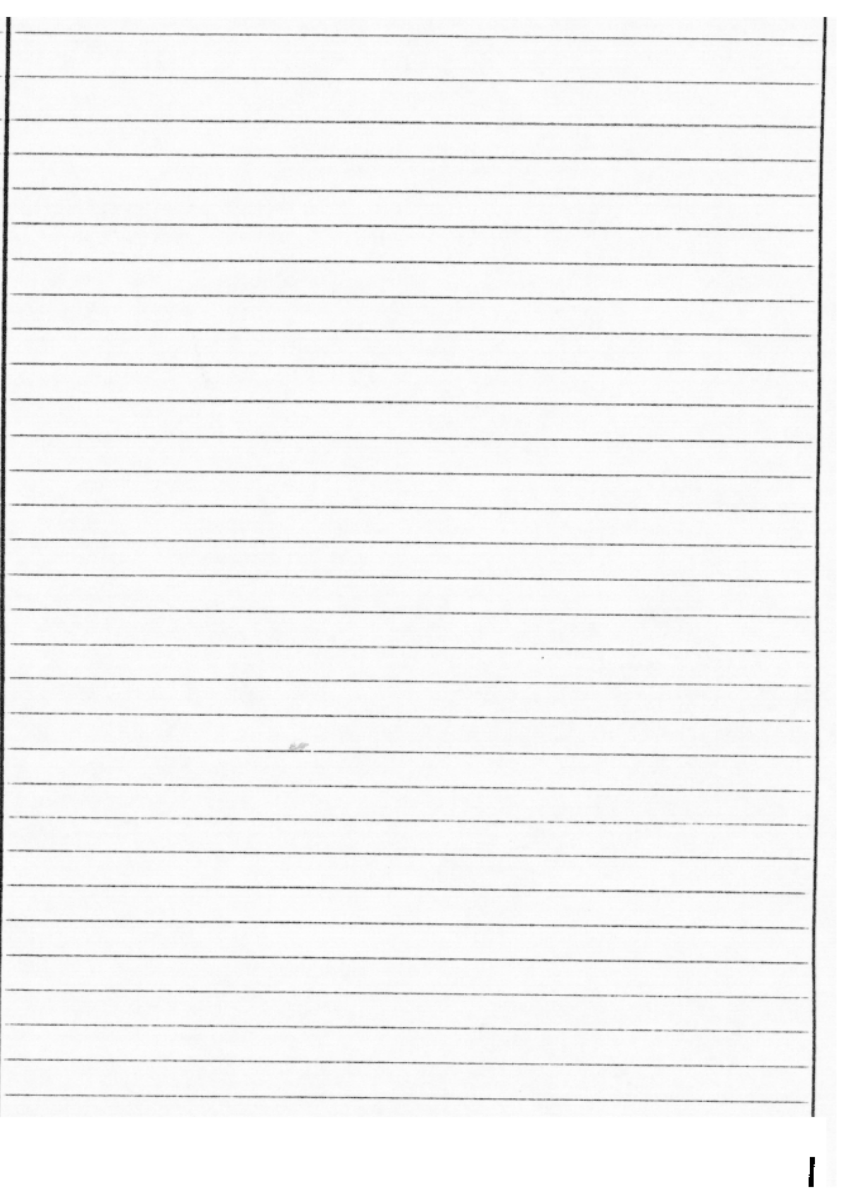


,$\cdots \cdot$ 


\section{Appendix F}

\section{MSO Process Demonstration Plan}


$\therefore$. 


\section{MSO Process Demonstration Plan}

\section{Criteria for Determining Success/Failure}

Waste treatment systems are tested in order to evaluate them relative to the Federal, State and local treatment standards, residual product requirements, and effluent requirements. Ideally, the MSO demonstration waste treatment system under evaluation will be shown to meet all LDR standards including the Universal Treatment Standards (UTS) for the chosen mixed waste streams. If successful, the treatment evaluation may result in the technology being designated by the EPA as a BDAT (or result in a Determination of Equivalent Treatment to the BDAT) for a specified mixed waste stream. A successful demonstration will result in a clear determination as to whether the MSO treatment process train meets the LDR requirements for the specific waste stream.

\subsection{Regulatory Acceptability}

Extensive test data are required to support a submission to EPA in support of categorical determination of BDAT or a Determination of Equivalent Technology for a one or more mixed waste streams. Less demanding demonstrations of LDR compliance may also be made as appropriate, such as treatment to produce residuals that meet the UTS; or partial treatment of a waste that, when combined with a specified secondary treatment of known capability, results in effective treatment of all constituents of concern; or preliminary evaluation of a promising technology deserving of additional or larger scale demonstrations. In general, requirements for designating a treatment system as a BDAT or as meeting Universal Treatment Standards are specific to both the treatment system used and the waste stream treated. The requirements for a successful determination may include showing that the treatment products and residuals have contaminant concentrations less than applicable UTS, the organic destruction and removal efficiency is equivalent to that obtainable by the currently prescribed BDAT [e.g., 0.9999 destruction and removal efficiency (DRE) for incineration], or a combination of these or other specifications.

Deployment of a waste treatment system in a treatment facility will require permits from the local as well as state and Federal regulators. A significant part of the charter of local regulators is to focus on the specific circumstances and environment in which the proposed treatment facility will operate such as the need to meet local requirements for air quality and waste water pretreatment. Demonstration of treatment systems will help to provide this data. Further, the demonstrations must comply with standards established by the San Francisco Bay Area Air Quality Management District and the City of Livermore's Water Reclamation Plant pretreatment standards.

\section{Evaluation Strategy}

This Section describes the general strategy and outline of operations for evaluating the MSO system to be demonstrated. 


\subsection{General Objective}

MSO is an emerging thermal technology for the processing and treatment of low-level mixed wastes and their by-products. Testing will provide, in an integrated pilot-plant scale treatment environment, the additional engineering test data, formal evaluation, and operating experience on a wide range of feed materials, to demonstrate that MSO can meet LDR requirements for a variety of mixed waste streams and to facilitate the deployment of MSO treatment systems in future waste treatment facilities.

\subsection{Demonstration Configuration}

Tests will focus on the demonstration of a single, integrated treatment train that includes all systems available within the facility needed to prepare and treat waste from its point of entry into the facility to the point at which all products, residuals, and secondary streams leave the facility having acceptable waste characteristics.

\subsection{Technical Evaluation}

Testing of an MSO integrated treatment train will provide baseline technical evaluation engineering data and operating experience to waste treatment facility designers. These data will allow facility designers to specify systems for their appropriate waste streams, design for the appropriate facility scale, obtain permits from regulators, and construct and operate future facilities. The engineering data will include feed handling/preparation and process performance (rates and compositions of input and output streams) over a wide range of waste compositions and operating parameters.

Operating experience and information includes ease of operation, stability to upsets, and reliability, availability and maintainability (RAM) data. To accomplish this evaluation, specific measurements must be made which are categorized as follows:

- Those measurements necessary to determine process treatability/performance. They include:

- residual compositions (determined for emissions to each medium),

- destruction/removal efficiencies for specific waste constituents,

- material balances (input and output concentrations, rates of product accumulations, etc.),

- leachability of constituents from final waste forms.

- Measurements necessary to obtain specific process knowledge such as bubble sizes and temperature gradients in the MSO reactor.

For specific feed materials, tests are performed to determine:

- material balances/DREs for treatability under nominal conditions. 
- system response parameters under off-normal conditions such as temporary loss or reduction in flow, power, etc.

- the optimum testing duration for specific system configurations and test objectives.

- an envelope of effective operating parameters for challenging material compositions that define the waste envelope.

- reliability/maintenance performance over long, continuous operation (up to $100 \mathrm{hr}$ ).

DOE and EPA standards and methods shall be applied to data gathering activities. For example, analytical data that are intended for use in supporting applications for equivalency is obtained using the waste handling protocols (including chain-of-custody procedures) and analytical procedures outlined by EPA in their compendium commonly referred to as SW-846. Further, these analyses will be accomplished by an analytical laboratory certified by California to perform the specific procedures as needed.

DOE QA/QC procedures cited in DOE/MWIP-15, January, 1994 will be applied as appropriate to the collection and handling of measurement/analytical data. Other quality procedures, good scientific practices, and good engineering practices will also be applied.

The duration of each test will be sufficient to accomplish the specific MSO demonstration objectives. Test durations are expected to run from one hour (e.g. parametric tests of destruction efficiency versus excess oxygen in the MSO reactor) to five 8-hour shifts (e.g. full treatment train test on a campaign of feed under nominal conditions), to 100 -hour operability tests of the complete system.

\subsection{Waste Feed Requirements}

Demonstrations of an MSO treatment system will target a wide spectrum of organic-containing waste compositions. It is important that test feeds cover a wide range of compositions and characteristics to ensure that demonstration data are useful to many users (e.g., facility designers as well as system operators), each with specific waste treatment and information needs. Both surrogates and wastes will be used to conduct system tests. Surrogate materials will be chosen to emulate key chemical and physical properties of the actual waste streams of interest. Using surrogates provides flexible and efficient coverage of a wide range of feed characteristics and compositions thereby allowing the investigators to carefully study and optimize processes for eventual testing with mixed wastes. Surrogates can also be prepared and characterized with more precision than waste, making analyses and data interpretation easier. Testing with actual mixed waste streams will substantiate the surrogate results and also demonstrate that the treatment processes are robust enough to accommodate the compositional variety found in actual waste streams. Surrogates will be prepared from entirely 
fresh materials with no waste content. They may contain nonhazardous and hazardous organics and metals, radionuclides, combustible and non-combustible solids, and water. Ideally, the chemical constituents of surrogates should not react with one another in unforeseen ways, they and their reaction products should be conveniently detectable, and they should not alter key operating conditions from those expected under actual treatment conditions. Surrogate batches must be consistent in composition so that results from test series are easily comparable. Surrogate formulations will be selected based on DOE guidance (DOE/MWIP-15 through 18, January, 1994), EPA guidance, and engineering test objectives. Additional funding will be required to have actual wastes prepared by the Feed Preparation functions using LLNL's Hazardous Waste Management division inventory of organic-containing low-level mixed waste. These wastes may be spiked with species or materials including hazardous metals, hazardous organics, radionuclides, or other materials.

The following DOE representative waste types were selected for initial MSO demonstration testing (also shown are the nominal feed rates):

Waste Category (WMIS Code \#)

Nominal Feed Rate

Aqueous organics/Trimsol oil

$\mathrm{kg} / \mathrm{h}$

$$
(2110,2120) \text { Note } 1
$$

Halogenated organic liquids 1.5

(2210) Note 2

Non-halogenated organic liquids (2220) Note 2

Predominantly combustible solids $(5440,5490)$ Note 3

Scintillation cocktails (6140)

Note 2

Note 1:

Organics with 5-15\% emulsified or dissolved water (e.g., Trimsol oil with $10 \%$ water) are assumed to be prepared by removing water from wastes that exist as aqueous emulsions or solutions with $>1 \%$ organic (e.g., Trimsol emulsion with $8 \%$ organic).

Note 2:

Organic liquid wastes containing up to $1.0 \mu \mathrm{Ci} / \mathrm{g}$ tritium and $>2$ weight percent hydrogen may be treated.

Note 3: 
This category comprises paper, cloth, plastics, rubber, wood, etc., and may contain small quantities of metal or glass object (which would be removed before treatment).

A near-matching set of waste categories has been identified in the LLNL lowlevel mixed waste inventory:

LLNL Site Treatment Plan Designation

$\begin{array}{llc}\text { LL-W001 } & \left(\sim 5.5 \mathrm{~m}^{3}\right) & 6400 \\ \text { LL-W008 } & \left(\sim 7.1 \mathrm{~m}^{3}\right) & 2210 \\ \text { LL-W009 } & \left(\sim 3.6 \mathrm{~m}^{3}\right) & 2290,2900 \\ \text { LL-W014 } & \left(\sim 13.7 \mathrm{~m}^{3}\right) & 2220 \\ \text { LL-W017 } & \left(\sim 50.7 \mathrm{~m}^{3}\right) & 5440,5490\end{array}$

One or more of these wastes will be used as feeds for the MSO demonstration which will be conducted as a series of treatability tests. It is worth noting that approximately $0.25 \mathrm{~m}^{3}$ of LL-W008 contains high levels (> $>50 \mathrm{ppm}$ ) of PCB and parts of other streams contain levels of tritium that meet the MSO system's acceptance criterion. These are considered desirable waste streams for demonstration purposes.

Approximately three times as much surrogate waste will be fed to MSO during the demonstration period as real waste. The majority of the surrogates will comprise principal organic constituents of the real wastes plus a number of organic compounds that are characteristic of other important waste types. Examples of the former are common solvents and oils, cellulosics, and common polymers (PVC, PE, ABS). Examples of the latter are aromatic solvents (benzene, toluene, xylene), organophosphates (TBP), sulfur-containing solvents (DMSO), hexachlorobenzene, and nitrogen-containing organics such as pyridine, nitrobenzene, and acetonitrice. A few surrogate formulations will be prepared that simulate the compositions of wastes such as PCB-contaminated oils or solvents.

\section{Records and Reports of Experimental Results}

Description of the actual test procedures, configurations, observations, and data shall be documented, using a combination of process run sheets, lab notebooks, electronic data acquisition, and analysis reports. Prior to completing a specific system run, a "Run Plan" will be developed detailing specific objectives of the run, data acquisition requirements, and any special data needs. At the conclusion of each run, a "Test Report" will be completed summarizing the run plan, detailing and analyzing the data, discussing the results, and clearly stating the conclusions of the test. These reports shall be prepared by the Principal Investigator. Copies of the data and formal reports shall be placed in the QA records file. 
A Final Report summarizing the above data and test conclusions will be prepared for the California EPA, the US EPA, and DOE/EM. 


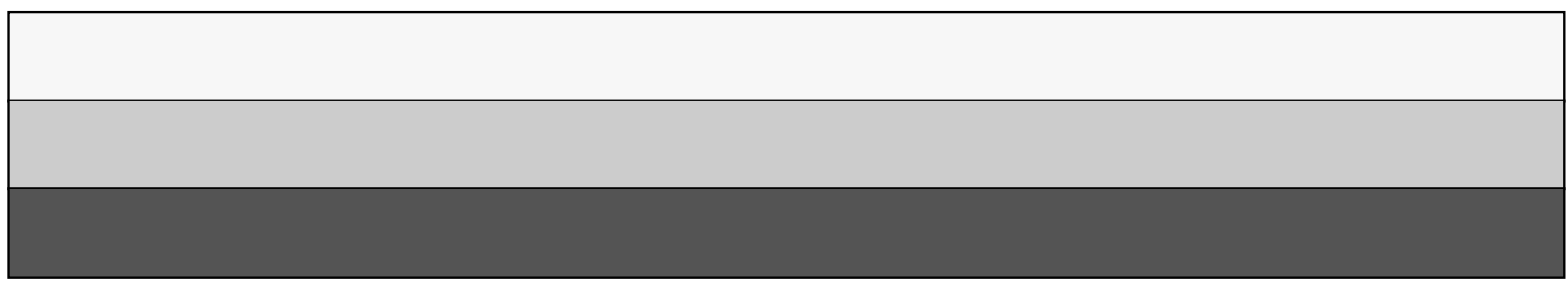

